\title{
»De sønderjydske Piger«
}

\section{- fra forlæggerprofit til folkeeje}

\section{af Inge Adriansen}

"De sønderjydske Piger« er et kært og skattet nationalt symbol i Sønderjylland, især kendt som vægbillede, bagsidemotiv på landsdelens mest udbredte folkelige værk, Sprogforeningens Almanak, ${ }^{1}$ og som prydelse i lidt ældre tid på alt muligt fra kaffekopper til pibehoveder, fra hovedtørklæder til cigarkasser.

Om billedets hovedaktører, de to piger, er der skrevet flere småstykker; ${ }^{2}$ derimod findes der ingen samlet redegørelse for ideen bag billedet, dets effektive markedsføring, store udbredelse og symbolets senere skæbne. Dette vil der her blive rådet bod på, og vi vil følge "De sønderjydske Piger«s forunderlige vej fra oprindeligt at være et rent kommercielt billede - fremstillet $\mathrm{i}$ håb om en let og hurtig fortjeneste - til at blive et sandt og ægte symbol på de dansksindede sønderjyders trofasthed og udholdenhed.

\section{Drachmann og Cathrine Fink i Bøffelkobbel}

Beretningen om, hvordan to piger med resignerende blikke - fotograferet $\mathrm{i}$ folkedansertøj foran et malet skovmotiv - kunne blive til et nationalt symbol, begynder i 1864. Efter den tyske hærs erobring af Als den 29. juni 1864 blev hele øen finkæmmet, og alt, hvad der fandtes fra den danske hær, blev medtaget, syge heste, der stod i bøndernes stalde, efterladte munderingsstykker, selv småting glemt ved det hastige opbrud. Af befolkningen føltes dette småligt og brutalt, og derfor blev der skjult adskilligt. I et erindringsværk fortælles således: "En ung Pige husede med Hjertebanken et Officersskærf i sin Kommodeskuffe, en anden gemte et Sabelspænde mellem sine faa Smykker, og de havde en Fornemmelse, som om de i det mindste ville blive ført til Spandau til Straf for ikke at have udleveret det. De troede, at de udførte smaa Heltegerninger, men de næsten alt for elskværdige tyske Officerer ville rimeligvis med et galant Buk have overladt dem alle Herlighederne, om de havde vidst om dem. Det kan være det samme; det var et troskyldigt Udslag af Taknemlighed mod vore egne, der fik de sønderjyske Ungpiger til at frede om de bortdragnes Efterladenskaber.« ${ }^{3}$

Til dette eksempel på sønderjyske pigers trofasthed over for alt dansk kunne der føjes mange andre; men vi vil nøjes med at fremdrage et enkelt andet: Cathrine Fink i Bøffelkobbel i Sundeved. Sammen med sine forældre passede hun "graven ved alfar vej火. I deres have blev begravet to danske soldater i februar 1864, og graven blev trods familiens fattige kår passet og plejet med 
kranse, blomster, bånd og små, hjemmesyede dannebrogsflag. Inde i stuen var samlet granatstumper, kugler og andre erindringer fra krigsårene.

Ved denne grav i Bøffelkobbel aflagde Holger Drachmann beseg i 1877. Digteren var på dette tidspunkt led og ked af den hjemlige politiske strid om forfatningen og den æstetiske debat. Han rejste derfor til »det danske Termopylæ«, som han kaldte Sønderborg-området og beså Als og Sundeved $i$ april 1877, 13 år efter krigen. Hans håb var at hente åndelig næring og kraft til en vakkende indsats over for det danske folk. Hans søn Povl Drachmann har udtrykt det således, at digteren var "... drevet frem af en indre Trang som han laaner fra selve Nationens Sjæl, efter at hente ny Kraft, nyt Haab fra den Jord, der er gennemtrukket med Folkets ædleste Blod, og give baade Kraften og Haabet videre til de vaklende Geledder $\mathrm{i}$ den nationale Tilværelseskamps evigt stridende Hjemmefront. $\ll^{4}$

Drachmann traf både Cathrine Fink og hendes gamle mor, og de to kvinder og deres indsats for at pleje de danske minder gjorde et stærkt indtryk på ham. Cathrine Fink skildres som en ung, høj pige med en bred pande, mørke klare, alvorlige øjne og en rolig værdighed $i$ alle bevægelser. Hun viser ham husets gæstebog og alle levnene fra de danske soldater, og bagefter går de ud til graven, og Drachmann beskriver det dybe indtryk, den sønderjyske piges omhu og trofasthed gør på ham:

"Jeg stod ved siden af den unge Pige, i sin tarvelige, klædelige Dragt, med dette noget $\mathrm{i} \emptyset \mathrm{jet}$, som ingen dansk Bondepige ovre fra Øerne skulde kunne fremvise. Jeg stod foran den Grav, som Fædrelandskærligheden havde indviet, Pieteten smykket. Vi danske fra Øerne er saadan et æsthetisk Folk. Jeg kunne, trods Pieteten og Fædrelandskærligheden, ikke undlade en lille Bevægelse i mit stille Sind: ja, dette er ærligt og smukt og varmt ment, men - lidt smagløst. Den unge Pige stod og saa paa disse Bomber og Fuldkugler med flagrende Dannebrogssløjfer, disse Græsrabatter med Tro, Haab og Kærlighed i Evighedskranse, og denne enfoldige Inskription over de faldne Krigere. Hendes Træk var saa rolige og hendes Blik saa fordringsløst, sikkert i al sin Troskyldighed, da hun vendte det mod mig og i sin dybe, faste Dialekt sagde: "Ikke sandt, det er saa kønt!« Da jeg trykkede hendes Moder, den gamle, halvblinde Kone, min skærv i Haanden, vendte Pigen sig bort. "Glem os ikke!« sagde hun, da jeg tog Afsked. Glem os ikke!

En stor, rigtudrustet Kunstner fra Renaissancen kunde maaske i et lykkeligt Øjeblik fængsle dette Udtryk i den sønderjyske Piges Øjne. En Stilist vilde selv med Opbydelsen af hele den moderne Kunst, staa hjælpeløs overfor Gengivelsen af Indtrykket. Men man har jo Lov til at fordre sig troet paa sit Ord, naar man taler ærligt og varmt til et Folk. Hvis alt det Haab, den Inderlighed, den dybe Resignation og den brændende Tro, som laa i dette 
Blik, kunne gennemtrænge det danske Folk, saa kunne en Vandringsmand derovre ved Grænsen begynde at tro paa en Regeneration hos det danske Folk .... $\ll^{5}$

Selv om Drachmann var maler, har han tilsyneladende ikke forsøgt at fastholde sin oplevelse af den sønderjyske pige i et billede. Derimod skrev han foruden det citerede prosastykke også et digt, der indgik i en rejseskildring fra Als og Dybbøl "Derovre fra Grænsen«, som han udgav sidst på året $\mathrm{i}$ 1877. I digtet lader han Cathrine Fink være et symbol på alle sønderjyske pigers trofasthed og håb:

"De vog dem, vi grov dem

En grav i vor have,

Lagde dem ved siden af den alfar vej;

Alle vore blomster skal smykke deres grave;

Sønderjyske piger, I forglemme det ej!

Hvem gemmer vi vel ellers vore kranse til!

Søster, hvad er det du siger?

Lad fjenden plukke blomster derude, hvor han vil:

Nælder hos de sønderjyske piger.

De ligger og lytter

I jorden dernede,

Lytter til hvert fodtrin på den alfar vej, Lytter, om på landsmål en læbe vil bede:

Sønderjyske piger. I forglemme dem ej!

Og skulle vi vel have så glemsomt et sind;

Søster, hvad er det du siger?

De døde har vi tegnet os i hjerterne ind;

De bor hos de sønderjyske piger .... ${ }^{6}$

Digtet blev ret hurtigt sat i melodi, og det blev meget populært som folkelig sang og blev optaget i Højskolesangbogen. Sangen var ikke blot med til at fæstne "graven ved alfar vej« i folks bevidsthed, men i høj grad også medvirkende til at udbrede og fastholde forestillingen om de trofaste, sønderjyske piger, der plejer de danske minder med omhu.

Såvidt Holger Drachmann. Det var imidlertid hverken hans ide eller fortjeneste, at den digteriske fremstilling af de sønderjyske piger hurtigt blev omsat $i$ billedform - og nåede en langt større udbredelse end nogen af Drachmanns værker. 


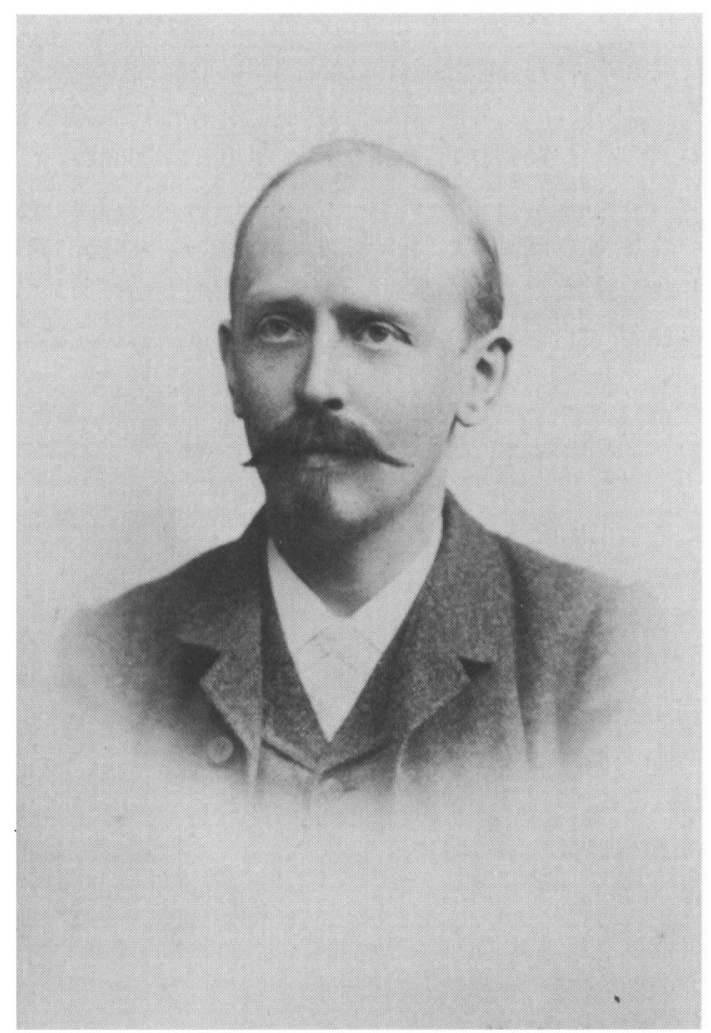

Fig. 1: Forlagger Ernst Bojesen (1849-1924), den initiativrige unge kabenhavnske forlagger, som gennem hurtig omsatning af salgbare varer sogte at skaffe sig en kapital til at blive bogforlagger. Det kongelige Bibliotek.

\section{Billedet af $» D e$ sønderjydske Piger«}

Ideen til at lave et portræt af sønderjyske piger, svarende til Drachmanns digt, opstod hos den initiativrige, københavnske forlægger Ernst Bojesen i 1879. Han var 30 år gammel og havde året før åbnet en papir- og kunsthandel $\mathrm{i}$ Vimmelskaftet. Det var en hård branche, og det gjaldt om at finde en niche. Bojesen havde store planer om bogudgivelser, men forlæggervirksomheden krævede en betydelig kapital. Kunne han blot få den rigtige ide til en meget salgbar artikel, så ville han med sin nye strøgbutik have uanede muligheder for at slå ideen op i store dimensioner. Imidlertid kneb det lidt $\mathrm{i}$ det første år med at finde den rigtige "sællert«. Det var dengang en udbredt fornøjelse at købe fotografier af kongefamilien eller populære skuespillere og sætte dem ind 
i svære læderbetrukne albums side om side med familieportrætterne. Også varer af denne art forhandledes af Bojesen, men med vekslende held. I 1878 blev den yngste af Christian IX's døtre, prinsesse Thyra, bortgiftet til hertugen af Cumberland, og Bojesen annoncerede ivrigt med billeder af hertugen uden noget videre held. Lidt bedre gik det med et fotografi af den populære skuespiller Emil Poulsen i rollen som Ambrosius, som han udsendte kort tid efter. Emil Poulsen spillede hovedrollen i et stykke af Molbech, som gik for fulde huse hele efteråret og vinteren 1878-79. Der blev talt om Ambrosius $i$ de københavnske hjem og købt billeder af Emil Poulsen til fotoalbummet.

Ambrosius-billedet bragte Ernst Bojesen en pæn fortjeneste, selv om det hovedsagelig var en københavnervare. Kunne han nu finde et billede, som ikke blot København, men hele Danmark måtte eje, så var hans lykke som forretningsmand gjort. - Med så direkte ord beskriver en biografi over Ernst Bojesen det mål, han sigtede mod med billedet af "De sønderjydske Piger «. ${ }^{7}$ Ideen opstod hos ham først på året 1879. Bojesen var blevet anmodet om at skaffe nogle biografiske data om Drachmann. Forespørgslen kom fra hans tidligere skolekammerat, Carl Steffensen, der var bosat i Flensborg og her skulle holde et foredrag om Drachmann og hans bog »Derovre fra Grænsen«. Denne forespørgsel fra Flensborg gav Bojesen ideen til det salgsstykke, som blev hans første store forretningsmæssige held.

I en artikel, skrevet i 1919, har Ernst Bojesen selv skildret, hvorledes ideen opstod, billedet udformedes og markedsførtes. Han sendte brevet til Drachmann, hvem han stod nær, og der kom hurtigt en fyldig biografi, som straks gik videre til Steffensen. "Samme dag slog Idéen med at lave Billedet "De sønderjydske Piger« ned i mig, og inden Dagen var gaaet, gik mit Brev af sted til Flensborg, hvor jeg udviklede Tanken for min Ven og bad ham nu hjælpe mig, som jeg havde hjulpet ham. Jeg bad ham søge at formaa et Par unge danske Piger til at gaa ind paa Tanken, bad ham skaffe originale Dragter og lade Byens bedste Fotograf søge at udføre Billedet saa smukt og stemningsfuldt som muligt.

Alt lykkedes. Proprietær Toftes to smukke Døtre hjalp os beredvilligt, og Fotograf Schumann løste sin Del af Opgaven paa smukkeste Maade. Ideer har jo som Regel deres Udspring fra et eller andet Berøringspunkt, og jeg formoder, at min havde sit fra, at jeg kort efter 1870 havde set franske Fotografier fra Alsace og Lorraine.

Da det prægtige Fotografi fra Schumann kom mig i Hænde, formaaede jeg Aug. Jerndorff til at ændre nogle mindre smukke Linjer i Staffagen, og til det færdige Billede tegnede Lorenz Frölich Randtegningen, hvori indflettedes de to smukke vers, som Vilh. Bergsøe skrev for mig ... $\ll^{8}$

Det ville have været naturligt at citere Drachmanns digt "De vog, vi grov« 


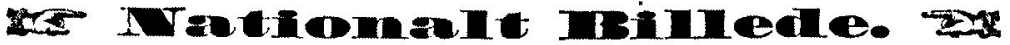

I naste Uge udkommer of for enhver Forrotolng 1 Fordon lotemigellgt Bulede, nenlig:

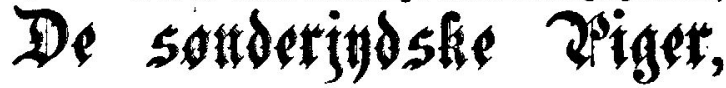

totograferede eftor Naturen af Fotograf R. 8chumann I Plonshort. Billedet or en overondentlig vellyktet og stemningsfuid Gjengivelse af to smukke sonderjydske Piger I Nationaldragter. Randtegningen om Fotografet or componeret at Lorens Frullob, Digtet $\mathrm{i}$ Randtegningen skrevet of Vilholm Borgsos. I hammen or ligeledos Indnettet Strofer af Holger Drachmanns Sang og Hillebrandts Melodi hertil. Prisen bliver: Meget otort Folio $10 \mathrm{Kr}$. - Folio (bade, hel Figur og Knestykle) 4 Kr. - Cabinat (ligeledes hel Figur og Knestykte) 1 Ir. 60 Bre. Alt

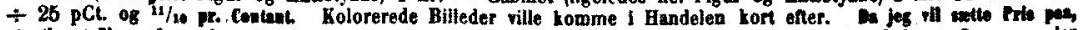

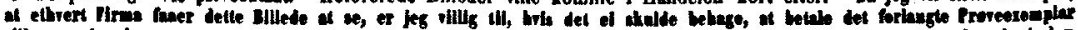

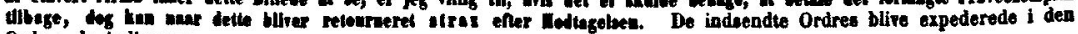
Orden, de indkomme.

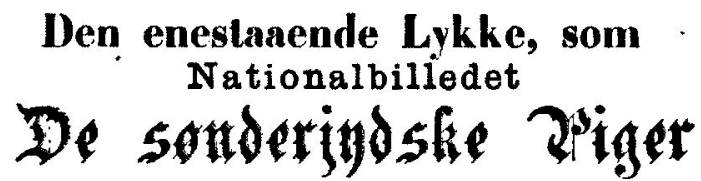

gjor i enhwer Egn of Danmark og Slezvig, har umuliggjort, at Jeg atadig har kunnet expeders alle de indkomne Telegrammer og threve pr. Omgasende, bvorfor jeg i saa Henseende beder dlierrer uodskylde. Navulig mas Ordrebe pas 10 og 5 Kroper-Billederae gas i den Orden, de indkomme, da der selvfelgelig kun er een Origialiplade og denne kan tun give 2.j Aftryk pr. Dag. Cabinets-Knastyke har jeg omirnt slet ikke hinnet lave, da jeg derred havde maattel undvere Folio-Billeder; delle vil dog tanae ordnes on nogle Dage. Fra farst i næste Uge haaber jeg alln Urdrer ville være expederede, ligesom at jeg da vil kunne tilfredsatille othvert forbrug. For difr. Boghaddlere, som endna ei have Forsynet sig, bemarkes, at Priserae er:

Stort Foljo $10 \mathrm{Kr}$. Folio Knestykke $5 \mathrm{Kr}$. Folio (hel Figur) $4 \mathrm{Kr}$. Cabinet Kr. $1,60$. Ernot Bojesens Kunetforlag.

Fig. 2: Bojesens heldige markedsforing af "De sonderjydske Piger" ses af disse to avisudklip. Overst annoncerer han $i$ Nordisk Boghandlertidende 18. april 1879, at billedet vil fremkomme en uge senere. Allerede den 16. maj kunne han sammesteds meddele, at det ikke var muligt at folge med den rivende efterspergsel.

under billedet; men Bojesen har måske fundet dette digt for stedligt bundet, så han nøjedes med at indflette begyndelseslinjen i den kunstnerisk udførte ramme. I stedet for fik han digteren Vilh. Bergsøe til at skrive nogle vers direkte til billedet, og Bergsøe løste denne opgave på få dage med digtet »Ret kan visne, Ret kan ældes«.

Den dansk-nationale identitet hos nordslesvigerne fremstilles her ikke som udtryk for et bevidst eller ubevidst valg af sindelag, men som et spørgsmål om valg mellem ret og uret. Bergsøe formår på mesterlig vis at gengive sit nationale budskab $i$ en salmetone med mindelser om Brorson, og associationen til den pietistiske, sønderjyske salmedigter er med til at give inderlighed og at understrege, at $G u d$ er med på retfærdighedens og de dansksindedes side:

"Ret kan visne, Ret kan ældes, Ret kan tabes, Ret kan fældes, 
Haabet, Haabet lever endnu

Det er det vi har tilbage

i de mørke Vinterdage,

Haab om Vaarens Solskinsstund.

Vi maa vente, vi maa bie,

I maa lide, I maa tie.

Sænk Jert Hoved - men hold ud!

Endnu Skæbnens Hjul kan vendes

Endnu Frihedsbaunen tændes

Ved et Solglimt sendt fra Gud.«

Gennem kompositionen af fotoet, Drachmanns linjer og Bergsøes strofer blev indtrykket af billedet meget stærkt og nationalt indigneret. Bojesen, der havde en veludviklet sans for salgspsykologi, var straks klar over, at han havde skabt en succes, og gennem en særdeles energisk markedsføring fik han billedet kendt over hele landet. Han fortæller også om dette meget bevidste salgsarbejde i den nævnte artikel i Politiken:

"Jeg glemmer aldrig den Dag, da jeg udgav Billedet. Jeg havde anbragt dette i mine festligt dekorerede Udhængsskabe, og Tilstrømningen var saa stærk, at jeg samme Dag solgte Rub og Stub. Nu strømmede Telegrammer og Breve ind fra hele Landet og fra Slesvig, og kun ved Udfoldelsen af min hele Energi lykkedes det at tilfredsstille den enorme Efterspørgsel. I løbet af Aaret fik "De sønderjydske Piger« en udbredelse på over 50.000 Eksemplarer, foruden at det anbragtes på Lommetørklæder, Pibehoveder og andre Brugsgenstande. ... Ja saaledes opstod og realiseredes Ideen, det gav mit første Forlagsheld og det første Stød til at naa mit Livsmaal - at blive Forlægger. «9

Klarere kan det næppe udtrykkes, at Bojesens eneste drivkraft og mål i denne sag var at skaffe sig en pekuniær fortjeneste. Han foregøgler ikke at have haft nationale motiver - og dette er bemærkelsesværdigt, da hans artikel er skrevet $i$ en nationalt bevæget tid, 1919, hvor mange gerne ville fremstå som forkæmpere for Sønderjylland.

Billedets betydning for Bojesens videre karriere kan vanskeligt overvurderes. Det gav ham tiltro til sit forretningsmæssige talent, og året efter »De sønderjydske Piger« lancerede han sin næste salgssucces, den humoristiske kalender "Oldfux«. Disse publikationer, beregnet på hurtigt salg til et bredt publikum, gav mulighed for, at han kunne bliver rigtig forlægger, og han opgav senere detailboghandlen og koncentrerede sig om sin forlæggervirksomhed »Det nordiske Forlag«. Han speciale i de første år blev dels børnebøger, dels fædrelandshistorie, idet »De sønderjydske Piger« havde vist, at der var klang- 


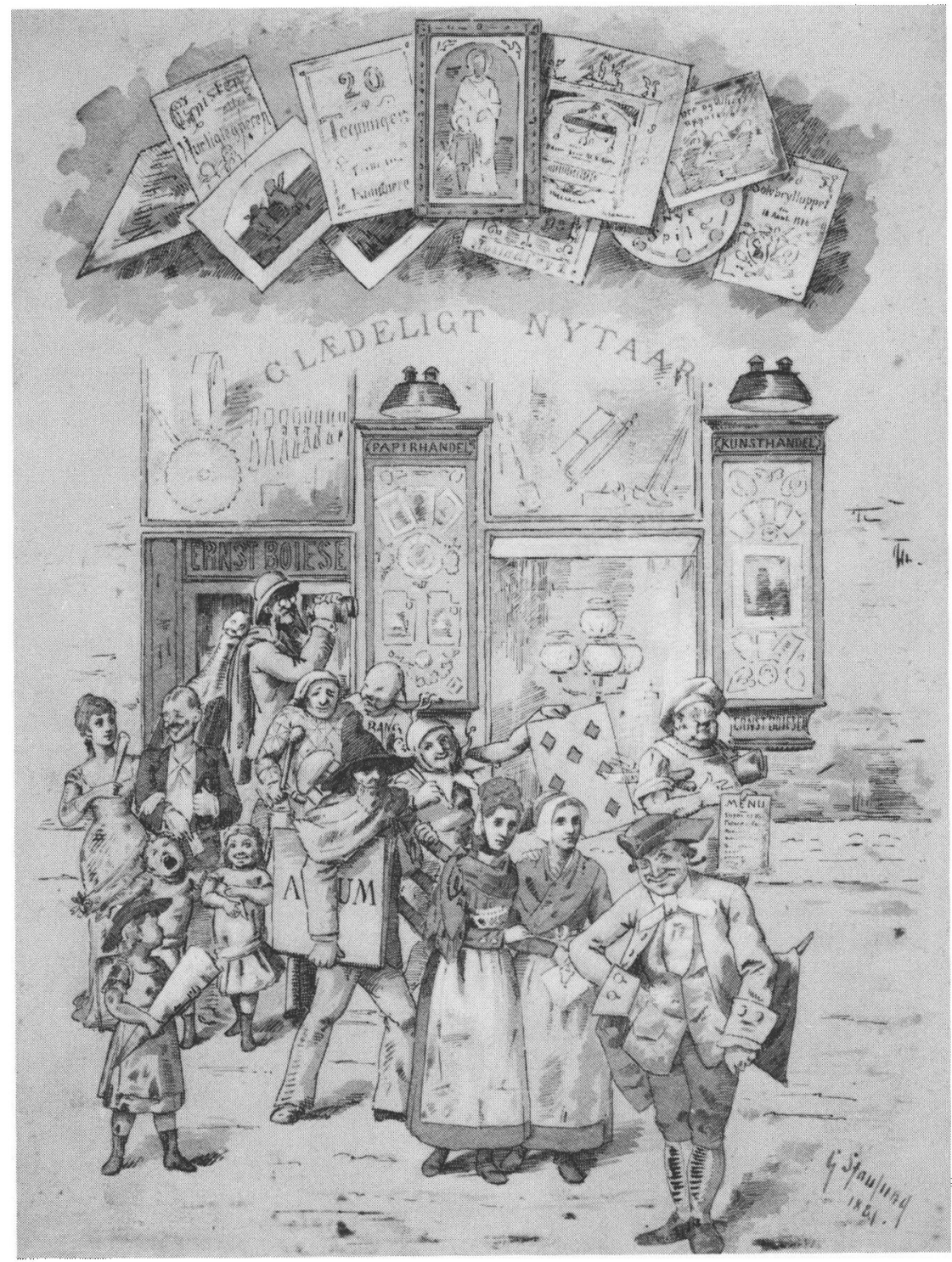

Fig. 3: Nytårshilsen til Ernst Bojesen fra hans medarbejdere til årsskiftet 1880-81. Her ses foran hans butik på Vimmelskaftet en broget skare af hans mest salgbare udgivelser. Det er et helt karnevalsoptog med den humoristiske almanak Oldfux forrest, bagved "De sonderjydske Piger", postkort og alt halløjet i form af kort og hefter med viser, brandere og muntre causerier. Privateje. 
bund i det nationale. Bojesen drev sit forlag op til at være blandt de mest fremtrædende i Skandinavien, og i 1903 blev det sammensluttet med Gyldendal, hvor han blev direktør.

"De sønderjydske Piger« var således grundstenen til en energisk og succesrig forlagsvirksomhed. Også Bojesens medarbejdere var klar over billedets betydning. Dette fremgår af et lykønskningskort $\mathrm{i}$ anledning af nytåret, som de sendte til ham i 1881. Her ses på en tegning Bojesens butik i Vimmelskaftet med en broget skare af hans salgssuccesser fra de sidste par år: Oldfux, "De sønderjydske Piger«, et kunstneralbum og alt selskabshalløjet i form af trykte kort. Det nationale billede indgår her klart blandt alle de øvrige kommercielle udgivelser af den lette art, som var firmaets levebrød på dette tidspunkt.

Denne konstatering af billedets oprindelse - som idé hos en energisk og $\mathrm{i}$ salgstal tænkende forlægger - indeholder ikke nogen ringeagtende vurdering af dets indhold eller betydning. Fotoet er smukt udført i tidens stil, og om billedets nationale betydning både i Sønderjylland og Danmark kan ingen tvivle. Men før der redegøres nærmere herfor, bør de to smukke piger på billedet præsenteres:

\section{Pigerne på billedet}

De to unge piger med de vemodige blikke var søstrene Helga og Valborg Tofte. Deres far, Hans Mikkelsen Tofte (1825-1917) stammede fra Tirslund sogn i Midtsønderjylland. Han var opvokset i et hjem, der var præget af såvel gudsfrygt som en levende fædrelandskærlighed, og disse følelser kom til at præge ham og give hans liv indhold og rigdom.

Efter at have taget lærereksamen blev Tofte ansat i Skærbæk og arbejdede her under Treårskrigen, som i særlig grad vakte hans danskhedsfølelse. Et lille træk kan illustrere den sammensmeltning af det kristne og det nationale, som skete for ham - og mange andre i samtiden. Efter den ulykkelige kamp ved Brøns den 22. januar 1849 samlede han sine skolebørn og fortalte dem om, hvad der var sket. "Der var blevet kæmpet, og mange var faldet, men sluttede han - skal vi saa ikke synge: Vor Gud han er saa fast en Borg! «10

Efter Treårskrigen fik Tofte ansættelse i Flensborg, dels som andenlærer ved den nyoprettede danske borgerskole, dels som degn i den danske kirke. Han faldt godt til, og arbejdet gav mulighed for, at han i 1853 kunne gifte sig med sin kæreste, en pige fra Styding. De fik fem børn, heriblandt døtrene Valborg og Helga, født i hhv. 1858 og 1861. Tofte kunne i tiden frem til 1864 glæde sig over lykke og fremgang både på det private plan og på det nationale, idet danskheden $i$ Flensborg var $i$ vækst og fremgang $i$ tiden mellem de to slesvigske krige. 


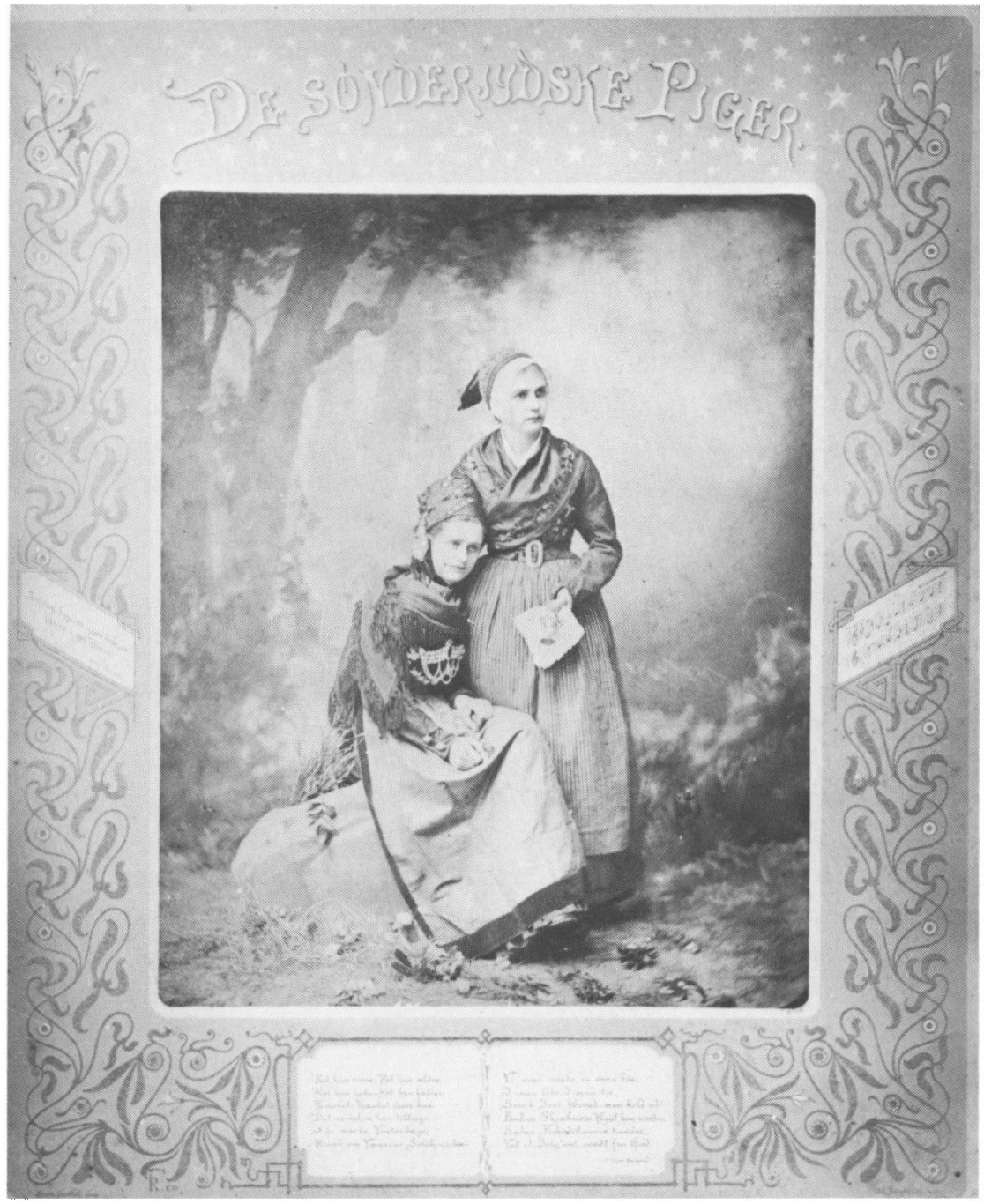

Fig. 4: Nationalbilledet "De sonderjydske Piger blev annonceret i Dansk Boghandlertidende 18. april $1879 \mathrm{og}$ udkom i maj 1879. Forlagget var et foto af sostrene Helga og Valborg Tofte optaget af fotograf H.Schumann, Holm, Flenshorg. Det solgtes ogsd som Cabinet-Portrat, sả de to piger kunne pryde $i$ familiealhums. Stroferne under billedet "Ret kan visne, Ret kan aldes ..." er digtet specielt til dette foto af Vilhelm Bergsøe. Det kongelige Bibliotek.

Alt dette blev slået i stykker med krigen i 1864. Lærernes løn blev beskåret efter krigen, og skolen chikaneret af de nye myndigheder. Da Tofte nægtede at aflægge eden til Kejser Wilhelm i 1867, blev han afskediget uden pension 
og måtte i et års tid leve under meget beskedne kår i Flensborg. I 1868 blev han ansat på den danske landbrugs- og højskole i Aagaard i Oversø sogn i Angel og blev det følgende år leder af skolen. Under meget vanskelige vilkår virkede Tofte her indtil 1889 , da skolen måtte lukke."

Det var fra denne danske forpost i det ellers fortyskede Angel, at Ernst Bojesens skolekammerat, Carl Steffensen, hentede de to piger til prøvefotografering hos fotograf $\mathrm{H}$. Schumann på Holm i Flensborg. Pigernes følelser over for opgaven kender vi ikke, men vi kan af billederne se, at de har bestræbt sig på gennem et bevidst valg af påklædning at fremtræde som et billede på Sønderjylland. Den ene, Valborg, var iført en alsingerdragt, mens den anden var iklædt en dragt fra Før. Både Nord- og Sydslesvig var således repræsenteret, og såvel Østkysten som Vestkysten. I en beretning om billedet fra 1911 fortalte Valborg, at dragterne tilhørte de to søstre. ${ }^{12}$ Måske har de været anvendt til folkedans på højskolen i Aagaard; Helga og Valborg var jo født og opvokset i bymiljø i Flensborg og har næppe haft kontakt med de forholdsvis isolerede egne og landsbyer, hvor der endnu omkring 1880 kunne findes rester af ældre tiders dragtskik. På Før var dragttraditionen på dette tidspunkt lidt mere levende end på Als, men også på Før var det især ældre koner, som ved kirkelige højtider endnu bar de gamle dragter og det fornemme dragtsølv. På det første prøvebillede stod begge piger op, men Helga med Før-dragten ser her noget forknyt ud. Det gør hun også på det endelige billede, hvor hun sidder ned og læner sig mod den stående Valborg. Helga Tofte blev få år senere angrebet af en galopperende svindsot og døde som helt ung i 1883. Hendes tragiske skæbne synes at ligge som en forudanelse i fotografiet. Hendes senere skæbne var kendt $i$ samtiden og var med til at forstærke billedets nationale budskab og symbolske kraft. Et eksempel herpå er et digt skrevet til hendes minde i 1890erne. Under et besøg ved hendes grav på Oversø kirkegård digtede overlærer Hans Rasmussen et langt vers til hendes pris, og det tungsindige indtryk fra billedet kommer her tydeligt frem:

... "Sorgen skyggede din unge Pande

Kindens røde Roser tabte Farven

Hjertet brast, og ung du sank i Graven.

Men du steg til Himmel som Valkyrie

for til faldne Helte Horn at række ... «13

Digtet er et tidstypisk udtryk for den tætte sammenvæuning af det kristne, det nationale og det oldnordiske, som fandt sted i grundtvigianske miljøer.

Den anden sønderjyske pige, Valborg, fik en langt lysere skæbne. Hun var en mere livskraftig natur, og billedet af »De sønderjydske Piger« blev i en vis forstand også hendes livs lykke! Hendes fætter, musiklærer H. Tofte ved 


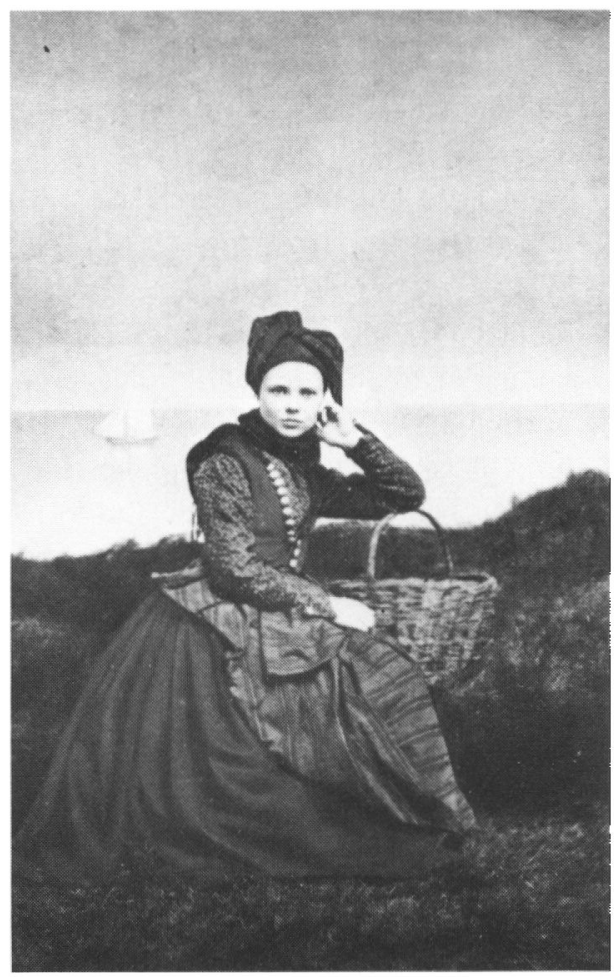

Fig. 5: "Pige fra Romow er et billede i serien "Danske Nationaldragter $i$ kolorerede Photografier, optagne efter Naturenk, som udsendtes af det kobenhavnske firma Hansen Schou og Weller i 1870erne. Her optrddte personer $i$ omhyggeligt udvalgt toj, ofte lánt hos fotografen, og baggrunden var akvarelmalet. "De sonderjydske Piger" fojer sig saledes ind $i$ en eksisterende tradition for billeder af smukke unge piger $i$ nationaldragter, og det minder $i$ opsatning meget om Hansen, Schou og Wellers serie, som sigtede pà at udnytte tidens interesse for det nationale $i$ en romantisk $u d-$ gave. Det kongelige Bibliotek.

Skårup seminarium på Sydfyn, så billedet og opdagede da, at hans kusine, som han ikke havde set, siden hun var barn, nu var blevet en meget smuk ung kvinde. Han knyttede atter forbindelsen til den sønderjyske del af familien, og allerede det følgende år blev han og Valborg gift og satte bo i Skårup. Hertil flyttede også den gamle degn Tofte i 1892 og tilbragte sine sidste 25 år i Valborgs hjem. Han døde her højt bedaget som 92-årig i 1917 - og fastholdt resten af sit liv et løfte, han havde givet sig selv i 1864, om ikke at klippe sit hår eller skæg, før Sønderjylland kom tilbage til Danmark. Det kom nok til at trække længere ud, end Tofte havde forestillet sig. Men hans frejdige tro forbød ham at svigte sit løfte, og han fik $i$ årenes løb et stateligt, patriarkalsk udseende med langt, hvidt hår og skæg.

Valborg var en stille, tilbageholdende kvinde, der ikke ønskede at blive fremhævet som model til »De sønderjydske Piger«, selv om hun næppe var i tvivl om billedets vakkende nationale betydning. Hun deltog i afstemningen i Flensborg den 14. marts 1920 og måtte her opleve den skuffelse, at hendes fødeby overvejende stemte tysk. Til gengæld blev det en stor glæde for hende 
at opleve sin datter og svigersøn blive præstepar i Bylderup sogn efter Genforeningen: Kredsen blev herved sluttet, da en gren af Tofte-familien vendte tilbage til Sønderjylland for at gøre en national indsats. Præsteparret blev energiske forkæmpere for danskheden $\mathrm{i}$ både Bylderup og Burkal sogne. ${ }^{14}$

\section{Billedets markedsføring og succes}

Billedet af $»$ De sønderjydske Piger« blev en i samtiden helt eksempelløs succes. Det udkom i en række størrelser, stor folio, folio, kvart og kabinet. Det første oplag på 500 var revet væk på to dage, og det kneb voldsomt med at efterkomme efterspørgslen. I en annonce i Nordisk Boghandlertidende i maj 1879 undskylder Bojesen, at der er ventetid på ordrerne og fremhæver, at »der selvfølgelig kun er een originalplade, og denne kan kun give 25 aftryk pr. dag«. Han fik dog hastigt flere plader til at lave aftryk efter.

Billedet blev i øvrigt ivrigt markedsført i boghandlernes fagblad, som wet for enhver forretning i Norden letsælgeligt billede«, og det blev fremhævet, at billedet var en "stemningsfuld gengivelse af to smukke sønderjyske piger i nationaldragter«. Forestillingen om de smukke trofaste sønderjyske piger, der sad og længtes efter Danmark, bliver her markedsført helt uden blusel. Ordet "nationaldragt" og myten om dette begreb var dukket op omkring 1850. Begrebet afspejler middelklassens og overklassens drøm om den idylliske, æstetisk tiltalende levevis på landet. ${ }^{15}$ Det er samtidig karakteristisk, at forestillingen om nationaldragter først udvikledes, da folk på landet de fleste steder havde kasseret tøj med egnspræg og var gået over til at bruge klæder, der bar præg af købstadskultur.

Billedet blev udgivet $\mathrm{i}$ en nationalt bevæget tid. I 1878 havde Preussen og Østrig slettet Paragraf 5 i Pragerfreden, og håbet om en snarlig afstemning var hermed udskudt på ubestemt tid. Samtidig var sprogstriden blevet skærpet ved indførelse af tysk undervisningssprog ved siden af dansk i alle landsbyskoler i Nordslesvig. Følelsen af, at der blev øvet uret over for landsmænd, var stærk hos mange danskere, og en nem måde at vise sin sympati over for sønderjyderne var at erhverve det nationale billede "De sønderjydske Piger «. Næsten alle samfundslag synes at have taget billedet til sig, og dets nationale mission understregedes af, at Bojesen lod det første eksemplar overrække til den sønderjysk fødte Kong Christian IX. Senere fremstilledes i øvrigt et eksemplar i legemsstørrelse til hans datter Dronning Dagmar af Rusland. ${ }^{16}$

En strøm af souvenirs med fotoet af $" D e$ sønderjydske Piger fulgte $i$ kølvandet på udgivelsen af billedet. I løbet af sommeren 1879 bestormedes Bojesen med forespørgsler fra fabrikanter, og for at sikre såvel lødigheden af 


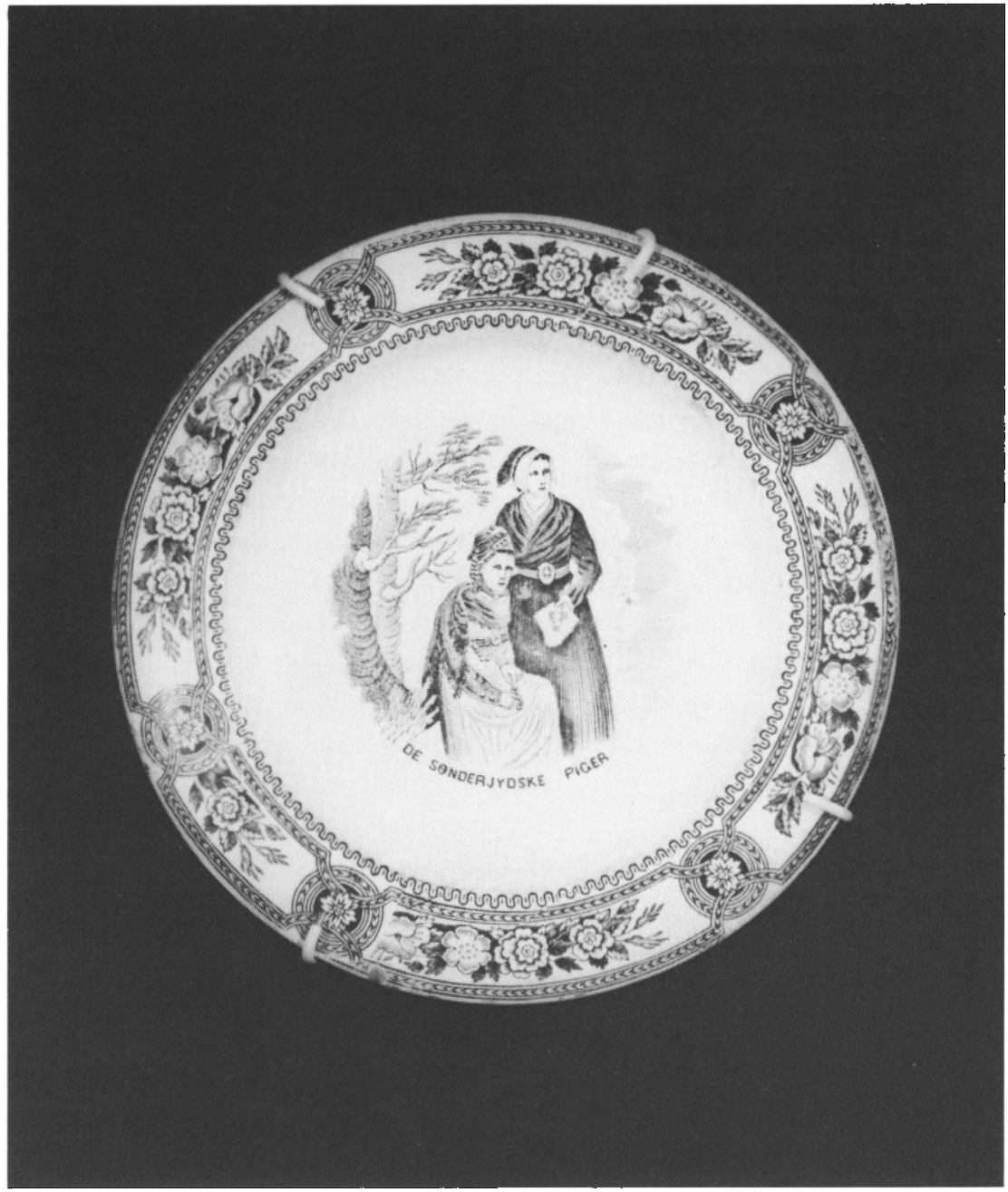

Fig. 6: Fajancetallerken fra stellet "Slesvig*. Pd bestilling af isenkrammerfirmaet Bucka og Nissen $i$ Kebenhavn fremstilledes dette stel pd en preussisk fajancefabrik i tiden omkring 1900. Den danske fajancefabrik Aluminia lavede $i$ ovrigt også tallerkener med «De sonderjydske Piger $i$ en lidt anden udgave. Museet pd Sonderborg Slot.

produkterne som en fortjeneste til sig selv indgik Bojesen aftale med firmaet Moritz F. Henriques om, at dette firma fik eneret til at forhandle galanterisager, hvorpå der var anbragt billedet af pigerne i glasfotografi." Denne ret til eneforhandling blev dog af begrænset værdi. Fra 1880erne dukkede der talløse piratudgaver af pigerne op på alskens sager, produceret i Danmark, Tyskland 
og i England. Det var varer som vaser, kaffestel, platter, pibehoveder, askebægre, tobaksdåser, bonbonnierer etc. Billedet blev ikke blot gengivet som glasfotografi, men også som stregtegning, i overførelsesbilleder på engelske fajancetallerkener og krus, som porcelænsmaling på askebægre og som farvelagte billeder på tysk porcelæn. Nedenunder billedet stod ofte trykt "De sønderjydske Piger«, men fra 1895 blev ordene "Sønderjylland « og "sønderjydsk « forbudt af de tyske domstole, og nu fremstilledes porcelænsstel med billedet og den sigende indskrift "De sønder...... Piger«. Dette stel, der vidnede om en urimelig og smålig national forfølgelse, var med til at fastholde billedets folkeyndest og understrege dets nationale budskab.

Bojesen var ikke den eneste københavnske forlægger med en veludviklet forretningsmæssig tæft, og en så stor succes måtte give andre lyst til også at prøve at slå på de nationale strenge. Julius Strandberg, samtidens største skillingsvisedigter og -forlægger, havde grundlagt sin virksomhed i $1863 \mathrm{og}$ fået det afgørende økonomiske fundament ved salg af dagsaktuelle viser til

Fig. 7: Sukkerskal fra et tysk kaffestel af porcelan fremstillet i 1880erne. Dekorationen er et overforingsbillede med en gennemsigtig glasur ovenpa.. Under billedet stär "De sonder..... Piger», og denne fremhavelse af det forbudte nawn var med til at gore dette stel sarligt populart. Det bor bemarkes, at stellet er tysk, fremstillet med henblik på salg i Sonderjylland. Museet pd Senderborg Slot. 


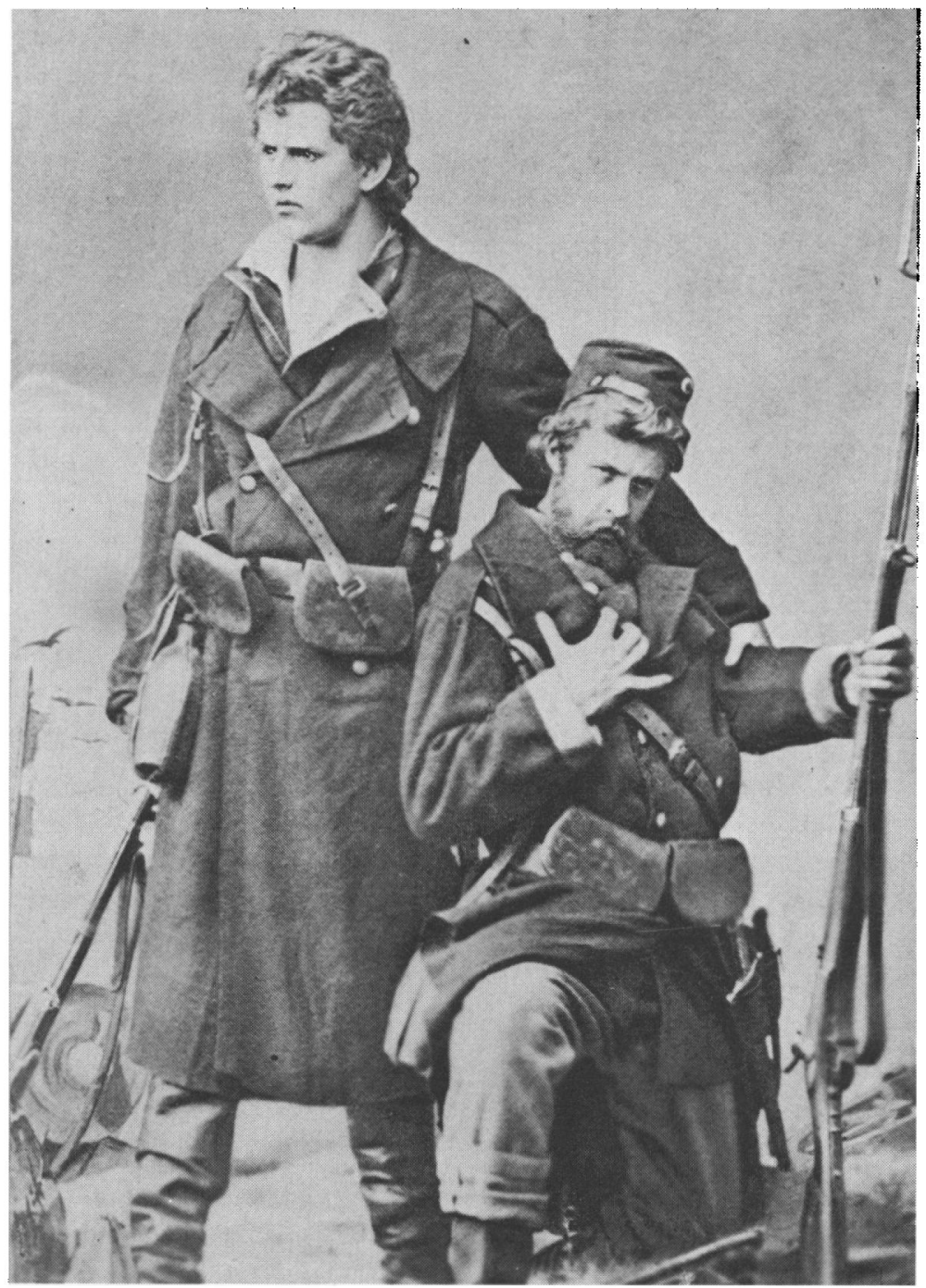

Fig. 8: "De sidste p̊̊ Skansenw. Modellerne er fra venstre balletdanserne Chr.Jensen og Hans Beck. Denne romantiske udgave med soldater med det dbne bryst gav anledning til mange spottegloser, og en ny udgave mätte derfor laves i hast. Museet pd Sonderborg Slot.

det nyhedshungrende publikum under krigen i $1864 .{ }^{18}$ Han havde ingen skrupler ved at lægge sig $\mathrm{i}$ kølvandet på Bojesens succes og udsendte omkring 1880 et skillingstryk med en vise på melodien »De vog dem, vi grov dem«. Her skildres en sønderjysk pige, hvis kæreste falder i krigen, og nu sidder hun ene 


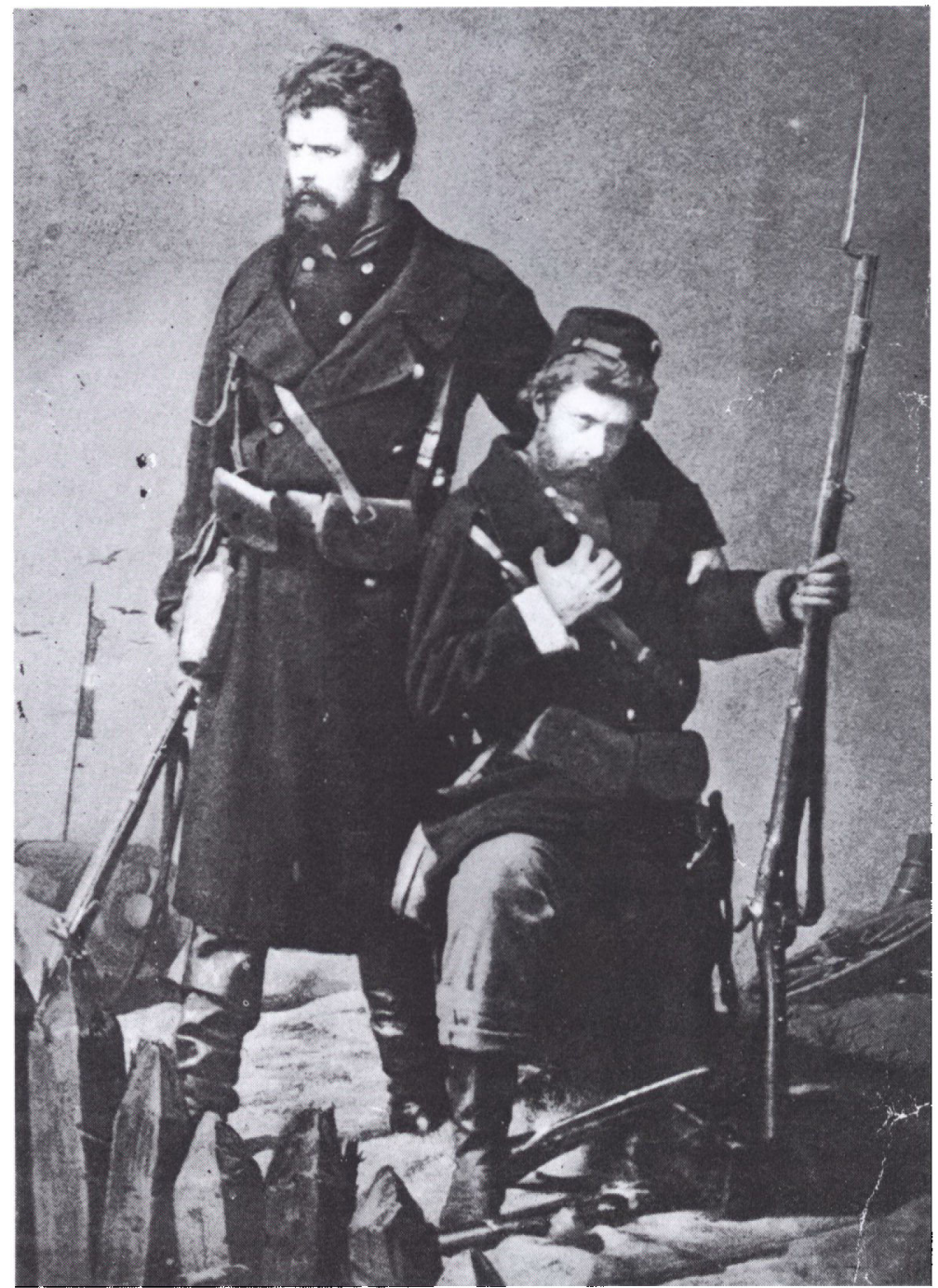

Fig. 9: "De sidste pd Skansen«. Pd dette billede har fotografen P. Fristrup forsynet den ene af modellerne med fuldskag, fjernet lidt af lokkerne og tilknappet uniformsjakken, så han fremstd̊r i mere reglementeret, men mindre romantisk udgave. De ledsagende vers var digtet af Vilh. Bergsøe. Museet på Sonderborg Slot.

ved graven, men roserne varsler et håb, og et sejrens råb trøster de sønderjyske piger. Det er en meget sentimental vise, karakteristisk for tidens skillingsviseproduktionen, som søgte at udnytte tidens rørelser mest muligt.

Fra tysk side blev man naturligvis opmærksom på billedets succes, og det 
var en rimelig tanke at prøve at overtage successen. Bojesen fortæller da også, at hans billede blev efterlignet $i$ Tyskland og vandt stor udbredelse under titlen "Unsere wiedergewonnene Schwester «. ${ }^{19}$ Der blev efter traditionen også gjort et tysk forsøg på at købe retten til det originale foto for at udgive det under titlen "Schleswig-Holstein «, men dette forsøg blev ikke realiseret..$^{20}$ Hverken Als eller Før ligger som bekendt i Holsten, og forsøget på at overtage symbolet har nok været for gennemskueligt. Den danske undergrund ville let kunne skimtes gennem en tysk fernis.

\section{"De sidste paa Skansen«}

Bojesens held gav - som allerede næunt andre lyst til at forsøge på at komponere tilsvarende »letsælgelige« nationale motiver. Blandt epigonerne var den københavnske fotograf Peter Fristrup. Han valgte at lave en direkte pendant - et par tapre unge mænd, der kunne hænge ved siden af de to trofaste piger på væggene over hele landet. Titlen var »De sidste paa Skansen«, og motivet var to menige, danske soldater på en sønderskudt Dybbølskanse. Fristrup fik Vilh. Bergsøe til at digte nogle strofer, og i hele sin udførelse var billedet således en tydelig parallel til $»$ De sønderjydske Piger«.

Imidlertid udeblev successen! Forklaringen herpå ligger nok $\mathrm{i}$ to forhold: Billedet »lugtede« for meget af fidus, og Fristrup havde ikke været heldig med modellernes kostumering. Han har selv i et erindringsværk meget åbenhjertigt skildret sin hensigt med billedet og dets uheldige udførelse: Han kunne ikke lade »den entreprenante og iderige« Bojesen ene beholde en salgssucces og gav sig derfor i kast med et modstykke. Men modellerne til de to danske soldater viste sig at volde vanskeligheder. Fristrup arbejdede især som fotograf for scenens navne, og han valgte da to balletdansere fra Det $\mathrm{Kgl}$. Teater til at agere danske soldater. Den ene, Christian Jensen var »høj, slank med en brillant Profil«. Den anden var en purung danser: »Lyshaaret, kæk og spændstig, med en mængde Foraarsknopper i Ansigtet. Det var Sønderjyden Hans Beck. Uden mange Omstændigheder var den unge Danser parat til at gaa $\mathrm{i}$ Døden for Fædrelandet og Fotografen «.21

Da billedet udkom, fik fotografen spottende gloser og skarp kritik i flere blade, fordi han havde idealiseret den ene af de to soldater, Chr. Jensen. "Han var fremstillet staaende, skægløs, med oprevet Skjortebryst og lange Lokker. Ikke ulig Schiller. Resolut lukkede jeg hans Skjorte, lod ham klippe og gav ham mørkt Fuldskæg. Men adskillige poetiske Naturer foretrak den første Udgave. Begge Billeder fandtes i Handelen. Dette gav et Vittighedsblad anledning til følgende Morsomhed: Damen (i Boghandelen): "Maa jeg bede om 
dygtig fotograf og samme lejlighedsdigter som Bojesen, kunne Fristrup ikke uden videre skabe en salgssucces og et nationalt symbol, som alle vil eje.

\section{De sønderjyske pigers besøg i København 1884}

Efter udgivelsen af billedet i 1879 blev »De sønderjydske Piger« hurtigt til et symbol på alle sønderjyders trofasthed over for den danske arv, deres tålmodighed og udholdenhed. I en tid, hvor kvinder ikke havde stemmeret og endnu manglede en række af de øvrige borgerlige rettigheder, blev $»$ De sønderjydske Piger « et helt usædvanligt symbol, og det synes at være symbolet, som i 1884 gav ideen til, at danske, patriotiske kredse inviterede unge sønderjyske piger til at aflægge besøg i København og Nordsjælland.

Rejsen blev en stærk manifestation af det danske Sønderjylland over for det københavnske borgerskab og en uforglemmelig oplevelse for de 300 piger, som deltog. Blandt disse var Marie Skau (senere Skau-Petersen). Sammen med sin søster Christine tilrettelagde hun turen p̊ opfordring af sin farbror, Peder Skau, Bukshave.

Han havde forbindelse med forstanderen på Vilvorde Gartnerskole i Gentofte, og herfra var der kommet bud til Peder Skau om, at en del familier i Gentofte og omegn gerne ville have besøg af ca. 50 unge sønderjyske piger. Trods betænkeligheder gik søstrene Skau ind på at forestå rejsen, der som nævnt blev en stor succes. Der meldte sig imidlertid så mange værtsfamilier, at 300 sønderjyske piger kunne rejse af sted. Søstrene Skau blev indkvarteret hos C.F.Tietgen, og denne havde udvirket, at Marie og Christine fik lejlighed til at hilse på kronprins Frederik, og at fire udvalgte piger kunne nedlægge en sølvkrans på Frederik VII's grav i Roskilde. Den danske regering havde ellers været meget betænkelig på forhånd, da man frygtede, at man fra tysk side ville opfatte kransenedlæggelsen som en politisk handling. Under festlighederne $\mathrm{i}$ København var der middag for de 300 sønderjyske piger på Skodsborg under forsæde af Københavns overpræsident. Christine Skau sad da side om side med digteren Vilh. Bergsøe, der havde skrevet verset nederst på billedet af $» D e$ sønderjydske Piger«. Under festen blev der i øvrigt sunget sange skrevet til lejligheden af Drachmann og Bergsøe, så associationen til det kun 5 år gamle billede var således tydelig under hele denne fest og på rejsen $\mathrm{i}$ øvrigt.

Turens højdepunkt var mindehøjtideligheden i Roskilde Domkirke og nedlæggelsen af en sølvkrans ved Frederik VII's gravmonument. Marie Skau fortæller herom:

"En forunderlig Stemning slog mig i Møde, en Stemning der gav mig en uhyre Smerte. Aldrig havde Sønderjyllands sørgelige Historie staaet for mig i 


\section{"Sonderjydske Piger, I for glemme

$$
\operatorname{det} \text { ej!" }
$$

Roskilde, $26-6-84$

Fig. 11: Bordkort fra festmiddagen for de senderjyske piger under deres ophold $i$ Roskilde 26. juni 1884. Kortet barer omkvadet pd Drachmanns sang: wDe vog dem, vi grov demu. Det vidner om, at besoget af de 300 senderjyske piger pa Sjalland $i$ juni 1884 var inspireret af Bojesens billede. Fra privatarkiv acc. 1406 i Landsarkivet, Aabenraa.

saa tungt et Lys, som i det Øjeblik. Det var Historien, vor fælles Historie, der tog mig saa stærkt til Hjertet og fik mig til at føle Adskillelsen fra Moderlandet som nogensinde før. $\ll^{24}$

Hjemkommet fra turen lod pigerne, der havde nedlagt sølvkransen, sig fotografere, og de lavede en opstilling, der helt svarede til »De sønderjydske Piger «s og foran et tilsvarende bagtæppe, som det fotograf Schaumann havde benyttet i 1879 . Men de afstod fra at trakke i egnsdragter, og de sorte kjoler, de bar, var også et langt bedre udtryk for sønderjyske pigers påklædning end Valborg og Helgas dragter havde varet fem år tidligere.

De sønderjyske pigers besøg i København er spændende, fordi det viser, hvorledes virkelighed og myte spiller sammen og påvirker hinanden - og ud af myten kan en ny virkelighed opstå.

\section{»De sønderjydske Piger« og Sprogforeningens Almanak}

I 1894 begyndte Den nordslesvigske Sprogforening udgivelsen af en almanak med en smuk blanding af folkelig lasning og praktiske oplysninger om vind og vejr, markedsdage og myndigheder. Omslaget var meget symbol-mættet: 


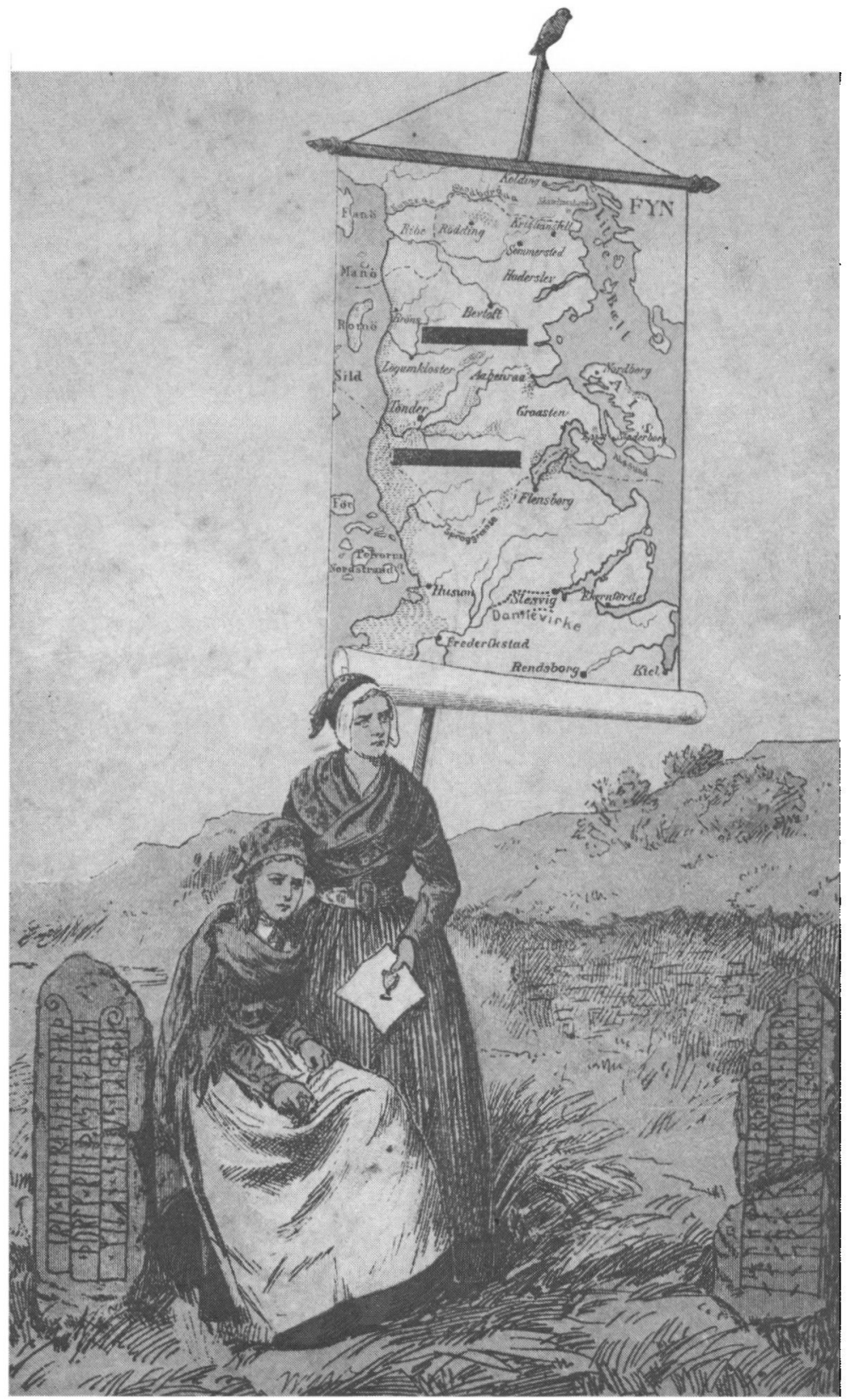

Fig. 12a: Sprogforeningens Almanak, bagsideillustration, herover 1896-1914 og til hojre 1960-79. I arene for 1. Verdenskrig ses de sorgende, resignerende, men udholdende piger med kortet med »et land uden navn". Men øverst oppe på kortstangen ses häbets larke. Billedet viser häb og tro. 


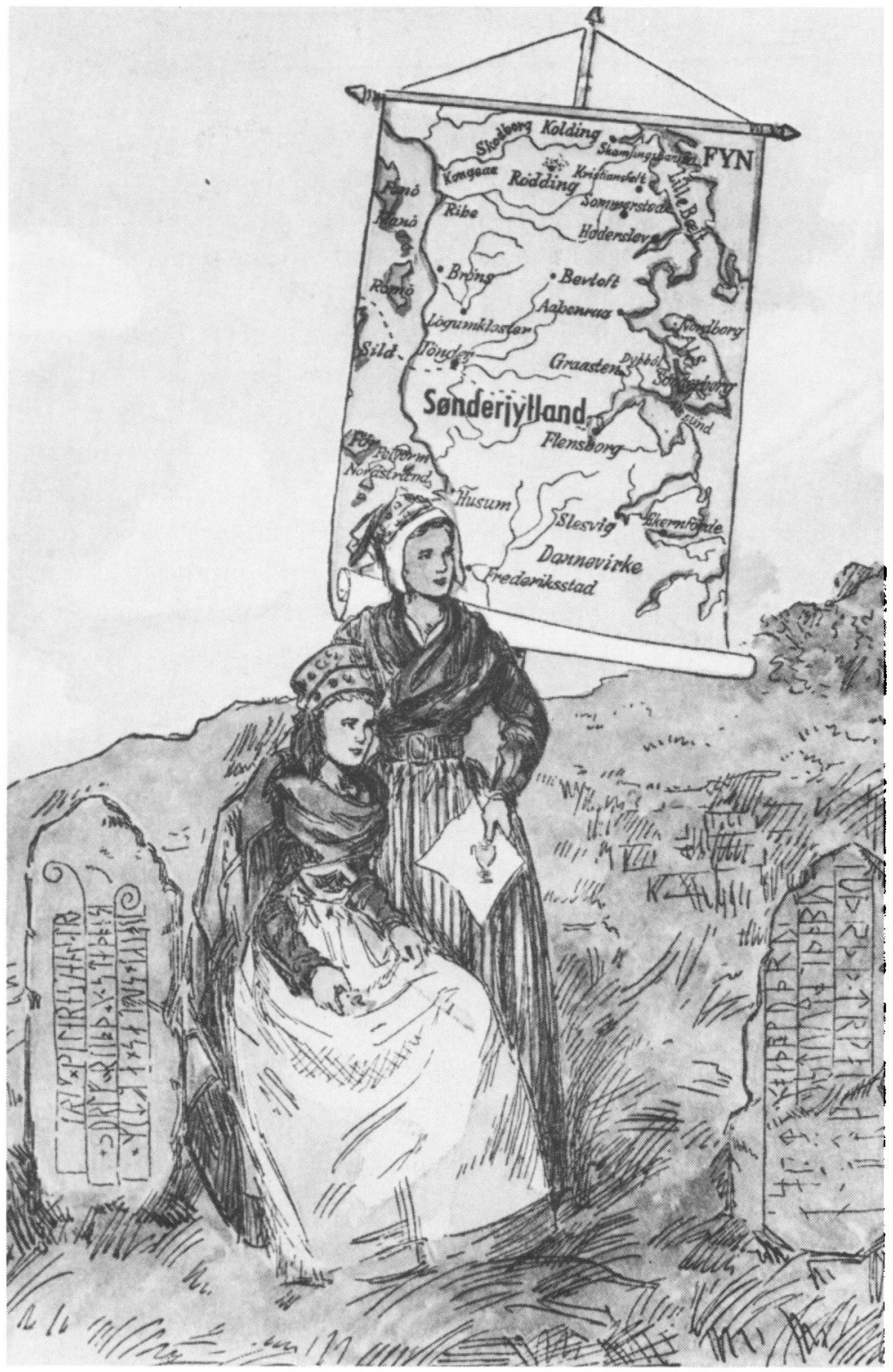

Fig 12b: I den andrede udgave efter 1960 er Helga og Valborg erstattet af to nette, unge piger, der med et venligt, abent blik frimodigt kigger mod syd. De frygter intet ondt, og deres landkort barer da også navnet Senderjylland. På kortstangen er håbets larke blevet til en knop. Der er ikke langere brug for håb og tro, når onskerne er opfyldte. 
På forsiden var gengivet støtten på Skamlingsbanken for at erindre om danskhedens vækkelse og sejrrige fremgang i 1840erne. Bagsidemotivet var en bearbejdelse af et populært billede af Mor Danmark med sværd i hånd beredt til at forsvare riget. ${ }^{25}$ Hun var gengivet kampberedt ved Alssund med et landkort over Sønderjylland i sin anden hånd.

Dette billede vakte imidlertid de tyske myndigheders mishag, og der blev $i$ 1895 rejst anklage mod Almanakkens redaktør, M.Andresen. Han fik en bøde, og hvad værre var, ordet Sønderjylland blev hermed forbudt. Bagsidemotivet blev derfor ændret fra næste årgang. I stedet for en stærk og modig Mor Danmark var her nu gengivet »De sønderjydske Piger « med de resignerende blikke. Kortet over landsdelen var bevaret; men med det famøse ord Sønderjylland slettet med tykke, sorte streger.

Mens Mor Danmark lyser af kampvilje og trods, er »De sønderjydske Piger« mere præget af stille sorg over udlændigheden. Alligevel er almanakbagsiden med pigerne nok det stærkeste nationale symbol af de to, fordi det ikke blot rummer resignation, men også udholdenhed, sammenhold og trofasthed. Kortet med det overstregede navn giver sammen med pigerne en fin illustration til en nationalpolitisk kampsang med salmetone, som var digtet i 1890 til sønderjydernes besøg i København. I denne sang, "Det haver så nyligen regnet $\lll$, begynder $3 . \operatorname{og} 4$. strofe således:

»Og de tro'de, at hjertebånd kan briste

og de tro'de, at glemmes kan vor ret

...

De kan lokke med farver og med prele

de kan lokke med løfter og med løn ..."

Men fra denne resignerende konstatering går digteren i hver strofe over til en stærk national bekendelse:

"... de skal vide, de aldrig ser de sidste

de skal vide, at ingen bliver træt $\ll$.

For mange sønderjyder har Almanakkens bagside med $" D e$ sønderjydske Piger« været en anskueliggørelse af den daglige, stilfærdige, uheroiske kamp, som var forudsatningen for at bevare den danske nationalitet $i$ tiden under tysk styre. Med krigsudbruddet i 1914 blev alt nationalpolitisk arbejde af ikke-tysk karakter stoppet, og almanakken måtte i krigsårene udkomme med et helt neutralt, billedløst omslag. Først med årgang 1921 var det igen muligt at bruge almanakken til nationale bekendelser, og Skamlingsbankens støtte kom atter til at pryde forsiden, mens bagsiden på ny blev indtaget af den stærke kvinde, Danmark. Ganske vist var det ikke med dansk kamp og sejr, 
at Sønderjylland var vundet; det var sønderjydernes egen udholdenhed, som havde muliggjort genforeningen. Imidlertid var det i 1921 vigtigt at vise, at alle gamle tyske forbud nu var slettet, og dette ønske gav det lidt hengemte, nationale symbol, Mor Danmark, en renæssance.

I 1960 fik almanakken en modernisering, og man valgte da at udskifte den kampberedte dannekvinde med »De sønderjydske Piger«. Men i overensstemmelse med det forbedrede klima i det dansk-tyske forhold efter 1955 undlod man at minde om den tidligere tyske censur, og landkortet blev gengivet uden de skæmmende og skræmmende, sorte streger. Også pigerne blev bearbejdet af en tegner, så deres triste blikke og lidt tragiske holdning forsvandt til fordel for en klædelig, pigelig mildhed. København-Bonn aftalerne havde tilsyneladende forbedret forholdet i grænselandet i løbet af kun 5 år, og den nationale symbolik måtte nødvendigvis afspejle den nye politiske situation.

Dette gør de nationale symboler også i nutiden: Ved at glimre ved deres fravær understreger de, at ikke ret mange af os ved, hvad vi skal stille op med det nationale begreb $i$ en tid med stedse større, europæisk og internationalt samarbejde på det politiske, militære og valutariske plan. Også denne situation afspejler sig på det lille forunderlige spejl af tidsånden, som findes på bagsiden af Sprogforeningens Almanak. I slutningen af 1970erne følte foreningen, at Almanakken trængte til en modernisering i sin ydre fremtoning. ${ }^{26}$ Man bad da den flensborgske kunstmaler Holger Hattesen om at nytegne for- og bagside. Det lykkedes rimeligt godt for forsidens vedkommende, men bagsiden blev et mærkeligt sammensurium - uden "De sønderjydske Piger « og kortet over landsdelen. Det viser, hvor svært det er for nutiden at forholde sig nogenlunde afklaret til det nationale begreb, når Sprogforeningen og en dansksindet sydslesvigsk kunstner i fællesskab ikke har kunnet løse opgaven med en modernisering af et kært og udbredt nationalt symbol.

Disse bemærkninger er kun konstaterende og rummer ikke nogen egentlig kritik, fordi talrige andre i årenes løb har brændt sig på forsøget med at skabe fornyelse $i$ det nationale skatkammer. Især $i$ tiden omkring afstemning og genforening var der mange bestræbelser af denne art, som det vil fremgå af det følgende. Eksemplerne er så talrige, at det må være rimeligt at nøjes med at se på de mere hæderlige resultater og at forbigå resten.

\section{»De sønderjydske Piger« omkring Genforeningen}

I afstemningstiden fik alle de nationale symboler, såvel danske som tyske, et fornyet liv, og "De sønderjydske Piger « blev nu omtegnet og anvendt i talrige, nye sammenhænge. Hvis man ser på billeder med dette symbol fra tiden 1919- 
Fig. 13: Postkort udgivet i Arhus 1920 med tekst af Viggo J.von Holstein-Rathlou. Kortets sammensatning af Istedloven og $" D e$ sonderjydske Pigerw viser det håb om en sydlig granse, som von Holstein-Rathlou og mange andre narede $i$ 1920. Det kongelige Bibliotek.

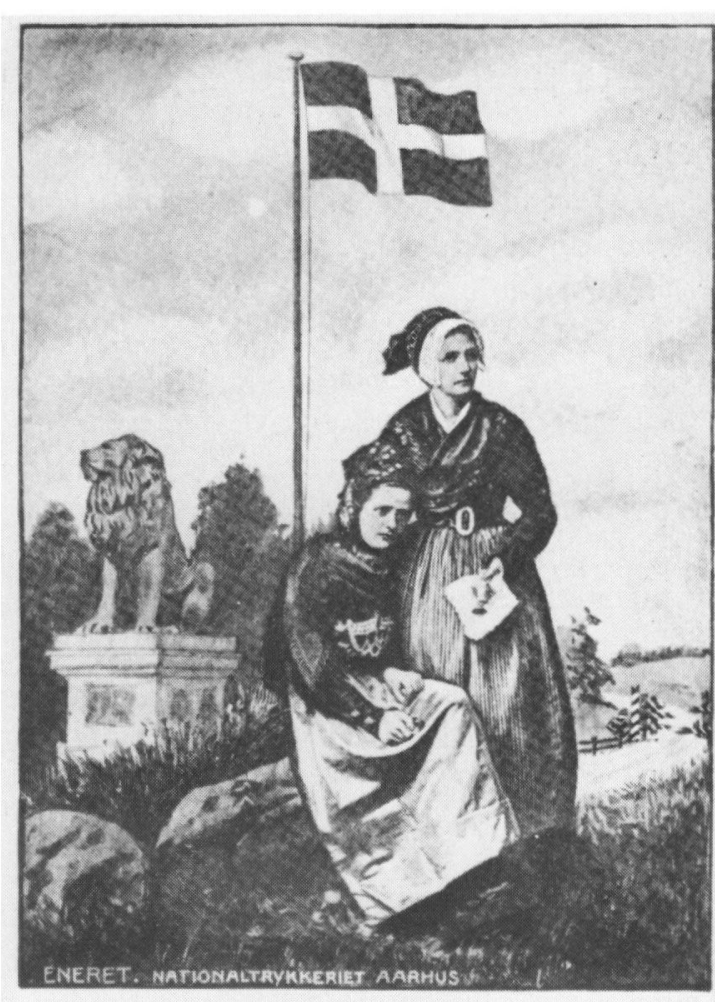

De sønderjydske
Piger.

Vi vented talmodigt i Tider saa trange;

vort Haab og vort Dannebrog holdt vi i Gem. Men snart ter vi synge de Danske Sange Ja. Gud vare lovet: Nu kommer vi hiem!

V. J. v. HR

20 , kan man møde alle grader af indtryk fra det rent patetiske over det meget kommercielle til det ufrivilligt komiske.

Det patetiske finder vi bl.a. i postkort udgivet af kredse med tilknytning til den stærkt nationalistiske liga, DDD (Danmark - Dannebrog - Danevirke). Her er »De sønderjydske Piger« anbragt sammen med Istedløven på en baggrund, der synes at være Danevirke. Verset under billedet udtrykker håb om, at Genforeningen snart forestår, og det er skrevet af en af de ledende kræfter i ligaen, overbibliotekar dr. phil. Viggo J.von Holstein-Rathlou. Han arbejdede ihærdigt for en grænsedragning så langt mod syd som muligt, helst ved Danevirke, og såvel motivet som verset er udtryk for hans stærke fædrelandsfølelse og tro på en guddommelig retfærdighed i grænsespørgsmålet. Denne opfattelse førte ham i øvrigt senere på vildveje. I 1938 meldte han sig ind i DNSAP og forblev her til den bitre ende i 1945. 


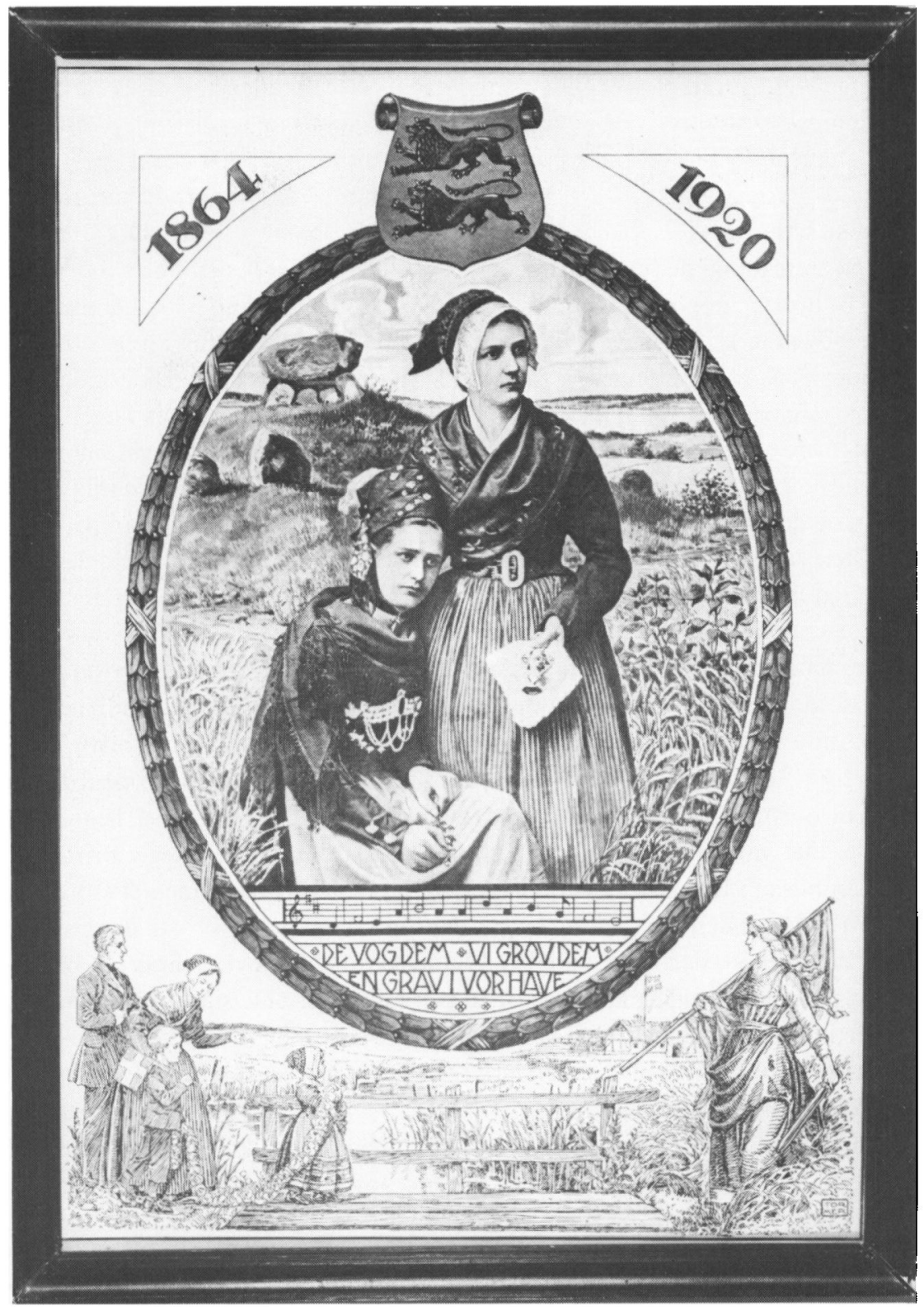

Fig. 14: "Hus og Hjemws Genforeningsbillede. Her er anvendt fotoet af de to Tofte-søstre indsat pd̊ en akvarelmalet baggrund med et arkedansk landskab med kampehoj og dyssekammer. Nederst en tegning. der viser Danmark, som modtager de hjemvendte senderjyder. Museet på Sonderborg Slot. 
Blandt de mere markante udgivelser $i$ anledning af Genforeningen var et billede udsendt af ugebladet "Hus og Hjem«. I midten ses Helga og Valborg Tofte anbragt foran et typisk dansk landskab, der skråner ned mod en fjord. En kæmpehøj med et dyssekammer hæver sig smukt bag pigerne, der kommer til at fremstå som et billede på en historisk kontinuitet, der rækker fra oldtid til nutid. Bergsøes digt med det smertefulde håb er ikke anvendt her, for nu er - med hans ord - skæbnens hjul vendt og frihedsbaunen tændt. Det fremgår også af en tegning, der er indsat nederst på billedet. Her ses en ung sønderjysk familie, far og mor med to børn, som over Kongeåen går Mor Danmark i møde. Danmark er gengivet i Elisabeth Jerichau Baumanns streg som på bagsiden af Sprogforeningens Almanak. I baggrunden ses en dansk bondegård i fynsk udgave med bindingsværk, stråtag med kragtræer. Her er flaget hejst for at byde sønderjyderne velkommen hjem. Det er Genforeningssommeren for fuld udblæsning, vi her møder. Billedet blev lavet $i$ et overordentlig stort oplag, og det blev både købt af private og anskaffet til folkeskoler og højskoler over hele landet, fordi det viste såvel udlændighedsårenes stille udholdenhed som Genforeningens glæde.

I afstemnings- og Genforeningstiden var det i øvrigt uhyre populært at opføre nationale skuespil og tableauer. Det sidstnævnte dækker over en form for levende opstillingsbilleder, som havde været yndede, også i udlændighedstiden. Anna Kjems har således skildret, hvorledes forsamlingshusindvielser i tiden før 1914 kunne gøres festlige ved hjælp af tableauer: "De optrædende kom til at stå $\mathrm{i}$ bengalsk belysning, og der var stille i salen, så længe det varede. Det var ret så betagende - skønt det må have været meget primitivt. Jeg kan huske sådanne billeder som "Danmark, vor Moder « med et stort flag enten $i$ baggrunden eller $i$ hånden på den optrædende, og så var der en flok piger bag scenen, der sang: "Dejlige Danmark, hør hvor det klinger" eller en anden nationalsang. Jeg kan også huske et billede af »De sidste på skansen«, og dertil blev der sunget: "De vog dem, vi grov dem en grav i vor have«. ${ }^{27}$

Lignende optrin tilsat "De sønderjyske Piger « blev opført i mange forsamlingshuse i forbindelse med afstemningen d. 10. februar 1920. I Svenstrup på Als indledte man tableauer med at vise de to længselsfulde, sønderjyske piger, og næste billede var Mor Danmark, der modtog en enkelt hjemvendt sønderjysk datter. De optrædende var sædvanligvis tavse, men bag scenen sang et kor ofte udvalgte fædrelandssange, mens optrinnet varede.

I forbindelse med afstemningskampen i Flensborg opførtes et tableau af danske spejdere. Her medvirkede både en Mor Danmark og hele tre sønderjyske piger, repræsenterende henholdsvis zone I, II og III..$^{28}$

Der blev også udgivet anvisninger på opførelse af nationale skuespil, hvor første scene var "De sønderjydske Piger« anbragt midt på scenen omgivet af 


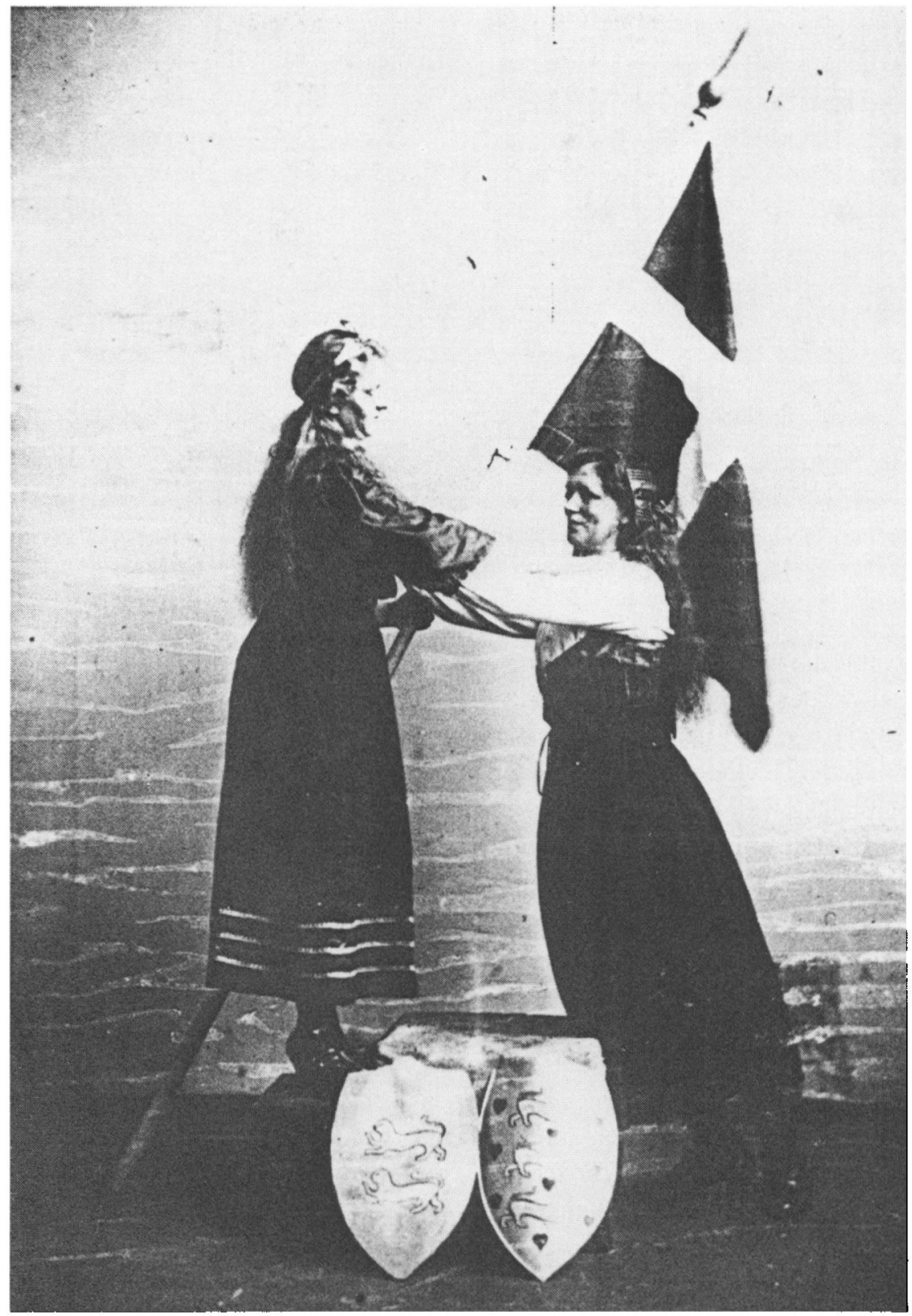

Fig. 15: "En rovet datter dybt begradt" vender her frelst tilbage til Mor Danmark. Scene fra tableau $i$ alsisk forsamlingshus 1920. Museet på Sonderborg Slot. 


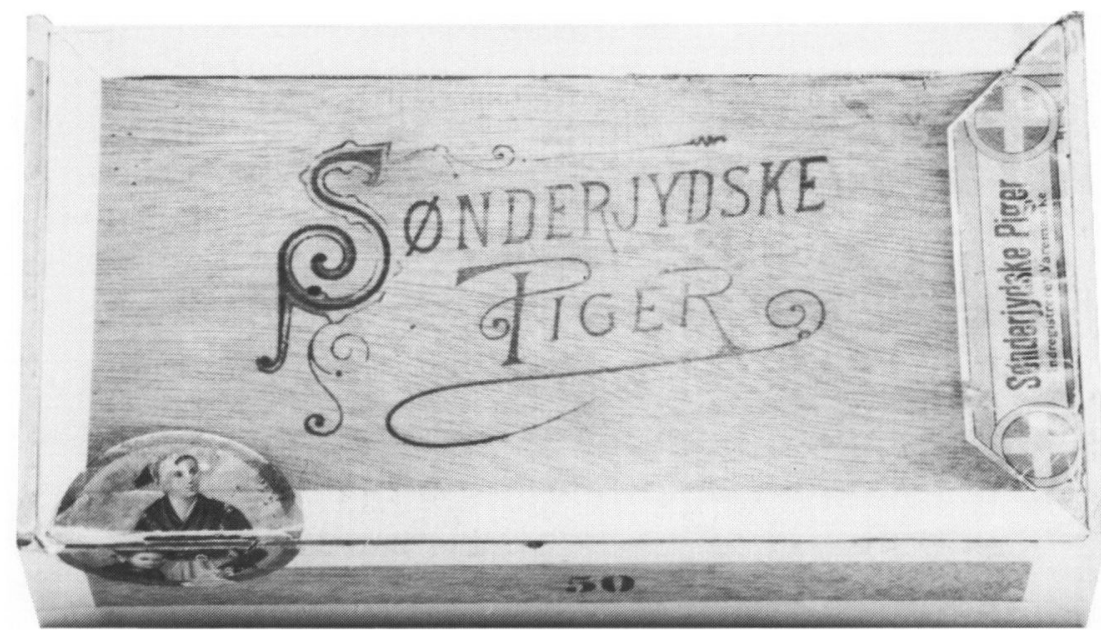

Fig. 16: Cigarkasse med cigarer med mavebalte med "De sonderjydske Pigerk. Fremstillet $i 1920$. Eksempel på den starke kommercielle udnyttelse af det nationale symbol. Museet pd Sonderborg Slot.

sortklædte piger, der sang $» D e$ vog dem, vi grov dem«. Dette optrin sluttedes med, at tæppet gik ned, mens forsamlingen sang »Du skønne land med dal og bakker fagre«. I de næste scener præsenteres først Danmark, derpå Genforeningen. En sønderjysk pige vender hjem, moderen fjerner hendes sørgeslør, og publikum slutter med at synge sidste vers af "Jeg elsker de grønne Lunde» med de forjættende ord, som mange fandt nu var gået $i$ opfyldelse:

"... end er der en Gud foroven, der råder for Danmarks Sag“

Talrige andre eksempler kunne anføres, men lad disse optrin være tilstrækkelige til at give indtryk af den overstrømmende varme og begejstring, der var knyttet til alt nationalt i 1920. Man skal lede for at finde et satirisk billede fra Genforeningen. Det synes at have været helt utilbørligt at gøre grin med de store følelser, og kun et enkelt eksempel har kunnet findes. Her betragter "De sønderjydske Piger« kongens ridt over grænsen på den hvide hest (se fig. 17). Satiren er rettet mod kongen og samtidens patos, mens pigerne går ram forbi. Heller ikke tegneren har følt trang til at latterliggøre dem, og det kan måske skyldes, at dette nationale symbol - i modsatning til mange andre ikke udtrykker magt og styrke, men derimod udholdenhed og trofasthed.

En vis kommerciel udnyttelse var billedet også genstand for i 1920, især var postkortfabrikanter ivrige, ikke blot med mange, ofte ringe gengivelser efter Bojesens oplæg, men også med omtegninger og brug af helt andre piger end 


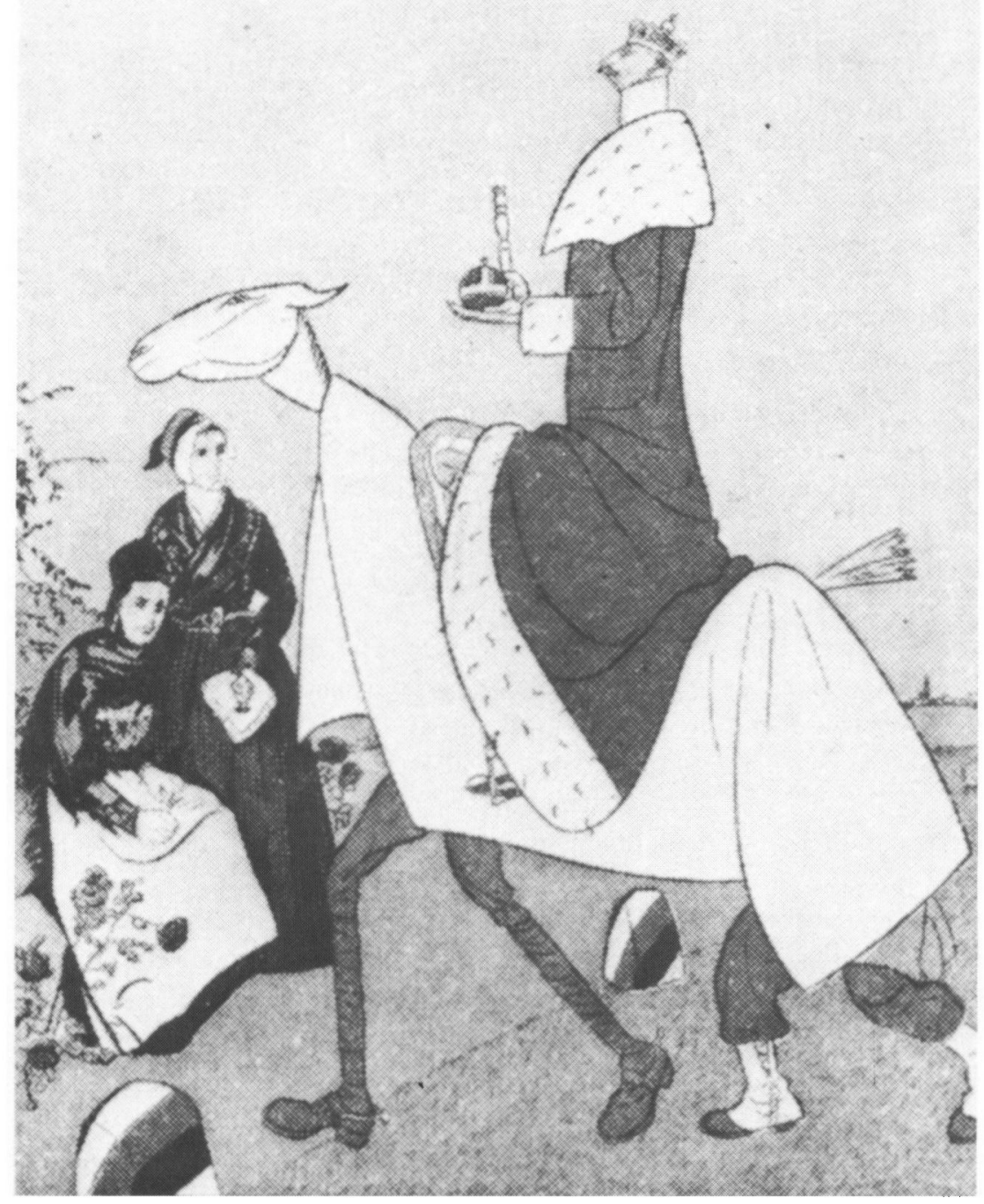

Fig. 17: Satirisk fremstilling af Genforeningen. Christian $X$ rider ned $i$ det genvundne land pd en hvid hest - som $i$ virkeligheden er en fransk og en engelsk soldat. Tegningen skal antyde, at Genforeningen skyldtes velvilje og hjalp fra de allierede magter. Gengivet efter Aa.Svendstorp og P.Moller: Folkestyret $i$ dansk humor. 1949. 
de oprindelige. Den kraftigste kommercielle udnyttelse blev nok præsenteret af firmaet Vibe-Hastrup, som brugte »De sønderjydske Piger « som blikfang for skosværte i Genforeningssommeren (se fig. 18). Også tobaksbranchen kunne bruge den nationale symbolik, og i 1920 kunne man således købe store, håndrullede cigarer af mærket »De sønderjydske Piger« med mavebælter med Valborg og Helga Tofte (se fig. 16).

\section{»De sønderjydske Piger« efter 1920}

Ved afstemningsfesten i mellemkrigsårene var tableauer fortsat et yndet indslag, og mange piger fik herved lejlighed til at prøve en første offentlig fremtræden under ikke-belastende forhold, idet de jo skulle forholde sig tavse og nøjes med at se pæne ud. P̊̊ Kegnæs, hvor man i 1920 stemte sig hjem med en overvældende dansk majoritet, 593 danske stemmer over for 16 tyske, blev der et par år senere holdt en afstemnings- og genforeningsfest $i$ Kegnæs Færgekro. Ved denne lejlighed optrådte præstegårdsforpagterens datter og hendes veninde som »De sønderjydske Piger«, mens en lokal grænsegendarm, skjult bag scenen, sang "De vog dem, vi grov dem«. Lignende optrin fandt sted over hele Nordslesvig i mellemkrigsårene.

Efter Anden Verdenskrig blev meget af det nationale arbejde rettet mod syd, og fra 1950erne svandt afstemningsfesterne efterhånden ind og med dem også fremførelsen af de nationale billeder. Efterhånden udvandedes traditionen, og begrebet »De sønderjydske Piger« kom til at omfatte mange andre end piger, der forsøgte at efterligne Helga og Valborg. Hvis et par glade unge piger, iført folkedansertøj af alsisk snit, lod sig fotografere sammen, så kunne billedet få betegnelsen "De sønderjydske Piger«, selv om der hverken var forsøg på at efterligne det oprindelige billedes opstilling eller holdning (se fig. 19).

"De sønderjydske Piger« overlevede til sidst kun på postkort, og som allerede næunt på bagsiden af Sprogforeningens Almanak. Især fotograf Biehl i Gråsten synes at have dyrket den nationale genre inden for postkortene, og der kendes adskillige udgaver af både »De sønderjydske Piger» og »De sidste på Skansen« fra dette firma i mellemkrigsårene. Men efter en opblomstring i besættelsesårene svandt interessen for det nationale begreb ind fra 1950erne, og i dag er det kun de færreste blandt de yngre generationer, som ved, hvad "De sønderjydske Piger« stod for engang. Det kan måske forbavse, at den nye kvindebevægelse, der opstod i 1970erne, ikke tog symbolet til sig. Men det var jo netop helt andre egenskaber end resignation og trofasthed, som kvinderne $\mathrm{i}$ begyndelsen af 70 erne havde behov for at opdyrke. Det var 


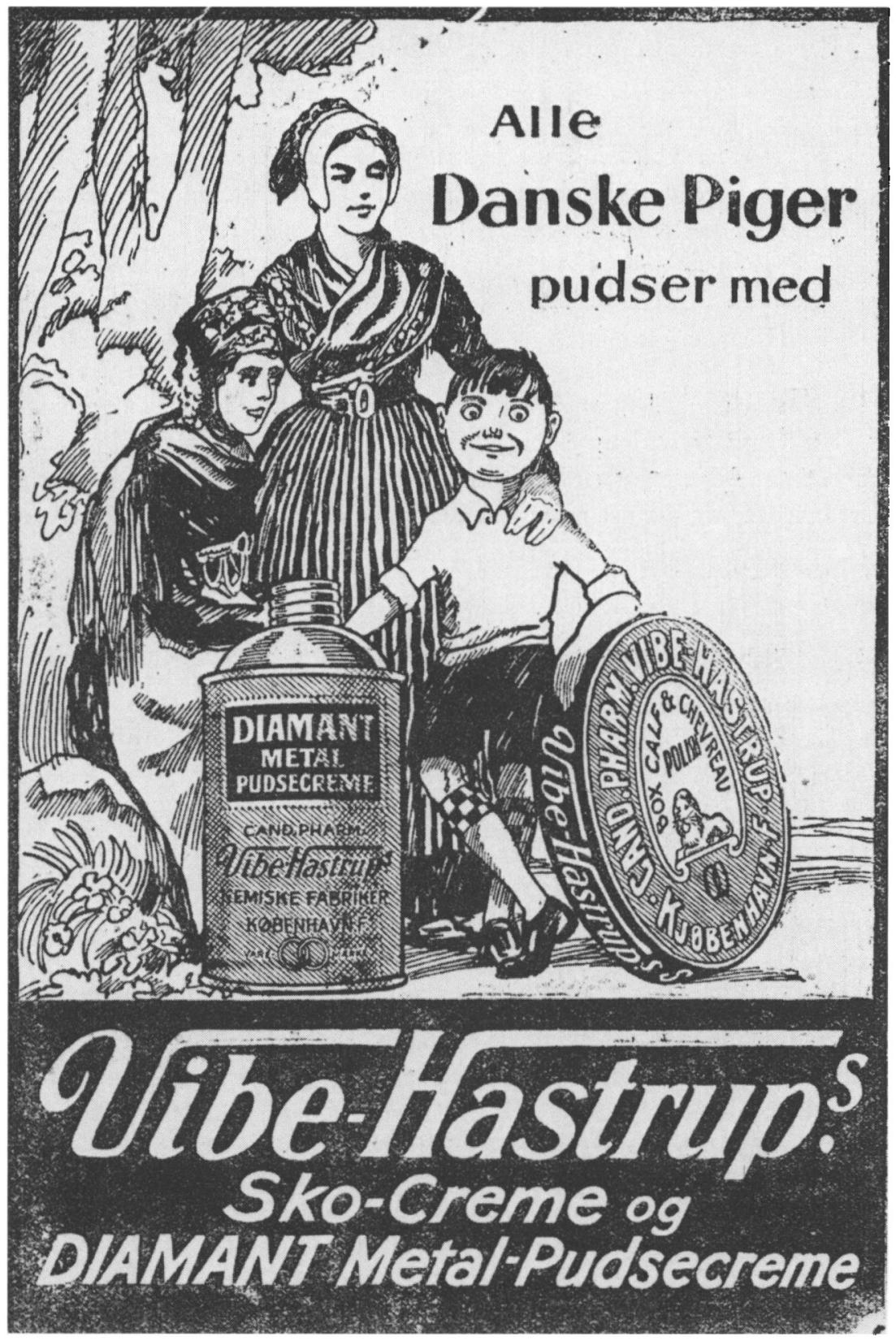

Fig. 18: Annonce fra "Modersmålet", juli 1920. "De sonderjydske Piger" kunne bruges i talrige forretningsmassige sammenhange. Her kombineret med Vibe-Hastrups dengang kendte logo, den lille dreng. 
derimod handlekraft og tro på egen styrke, det nu gjaldt om at mobilisere, og på disse områder kunne Helga og Valborg Tofte ikke inspirere.

\section{Livsholdning og symbol}

Symboler er altid udtryk for en holdning til og en tolkning af et fænomen. Det nationale billede "De sønderjydske Piger« afspejler således en bestemt opfattelse af udlændighedstiden - troen på, at stilfærdig udholdenhed, inderlig trofasthed og håb om Guds hjælp til sidst vil bringe retfærdighed, dvs. Sønderjylland tilbage til Danmark. Denne tolkning af billedet bekræftes af flere vidnesbyrd om dets betydning i forskellige danske hjem.

Forstander Chr. Demuth, Nordborg har beskrevet billedets rolle for hans valg af livsmål $\mathrm{i}$ artiklen »Håb og Tro« $\mathrm{i}$ DSK-årbogen $\mathrm{i}$ 1956: "På væggen ved siden af mit arbejdsbord hænger et gammelt, lidt falmet, men dog stadig klart billede. Dér har det hængt siden min far døde i 1918. Og da havde det haft sin plads over hans skrivebord i fyrretyve år. Det var den første gave, min mor har givet min far, da de var forlovede, så det kunne jo fortælle en del, hvis det fik munden på gled, og det gør det for resten engang imellem, fortaller om dem og deres livsindstilling - deres tro, da de var unge. Det kan måske også fortælle mine læsere lidt om min oprindelse, mit hjem og årsagen til, at jeg ... efter genforeningen var lykkelig for at få mit virke syd for Kongeåen og nu er taknemlig for at have fået lov at færdes mellem dem, der kom tilbage ... . $^{29}$

I lignende ord, men på vers, har stiftsprovst Christen C. Hjortkjær fra Haderslev i 1920erne skildret sin oplevelse af billedet og den påvirkning, det har givet ham i retning af at virke for Sønderjylland:

"De sønderjydske Pigers Sang er mig en Barndomsrøst, der fulgte mig i Verden ud fra Nørrejyllands Kyst, ja før jeg kunde læse, jeg kunde denne Sang, og den har fulgt mig trolig på hele Livets Gang.

Men også deres Billed, de kendte "Søstre to« har været i mit Eje og i mit Hjertes Bo,

fra jeg var Dreng derhjemme og hørte i vort Lag om Sønderjyllands Saga og Sønderjyllands Sag.

Min "Sønderjyllands Kærlighed" og "Sønderjyllands Haab»

fik gennem disse Toner sin allerførste Daab, og gennem dette Billed jeg altid saa den Flok, som »stod og sad" og ventede - og havde Modgang nok. 

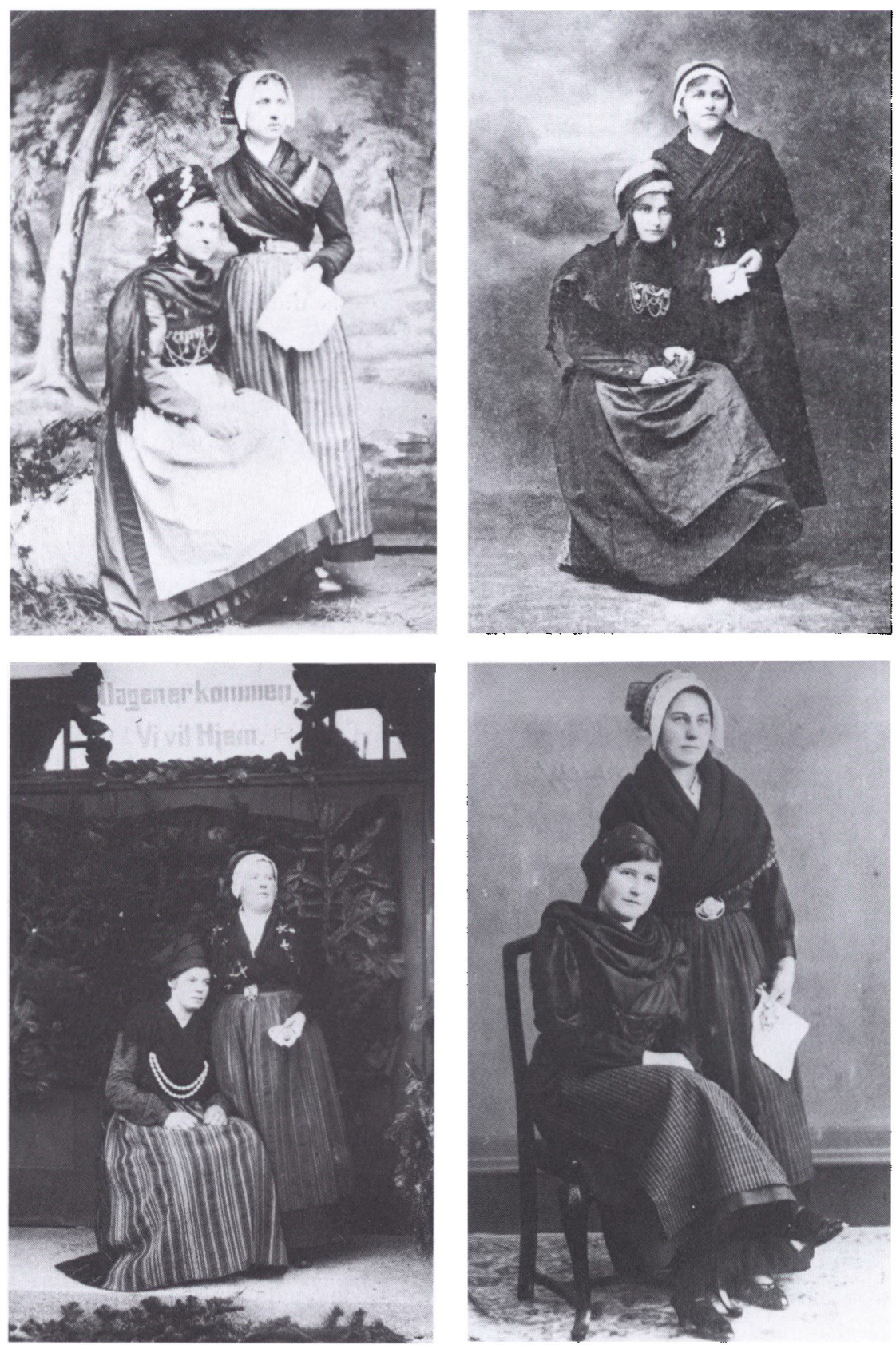

Fig. 19: Det blev mode for unge sonderjyske piger at lade sig fotografere $i$ kostumer og positur som "De sanderjydske Piger«. Her er et skansomt udvalg blandt mange billeder. Overst til venstre: Foto fra fotograf C.W.Olin i Sonderborg, ca. ar 1900-1914. Det kongelige Bibliotek. Overst til hojre: To ukendte modeller. Det kongelige Bibliotek. Nederst til venstre: To unge piger fra Svenstrup, fotograferet $i 1920$. Museet på Sonderborg Slot. Nederst til hojre ses Kathrine Mathiesen og Midde Koch fra Kegnas, fotograferet ved en afstemningsfest i 1920erne. Museet på Sonderborg Slot. 
Men sælsomt skifter Tiden, og saa kom da den Dag, da Sønderjylland hejste igen det danske Flag, - »de sønderjydske Piger $i$ Billed og Sang fik atter deres Hjemstavn i gamle Danmarks Vang.

Og jeg blev Præst dernede og stod en skønne Dag forundret i en Præstegaard, Gæst under Hjemmets Tag, »de sønderjydske Piger« fra Væggen paa mig saa den ene hun var Bedstemor til Prestekonens smaa.

$\mathrm{Nu}$ har jeg i mit Eje et Billed mig saa kært af denne Bedstemor, mit Barndomsminde nært.

- Hvordan skal jeg Dem takke? - fra Dem en ukendt Mand, jeg lover Dem at virke for Sønderjyllands Land. «0 $^{30}$

Det er næppe tilfældigt, at disse skildringer af billedets betydning er skrevet af henholdsvis en lærer og en provst. Det var $i$ sådanne folkeopdragende kredse, at bevidstheden om det nationales værd trivedes bedst. Forestillingen om et nationalt fællesskab uafhængigt af alle sociale skel har altid været mest udbredt $\mathrm{i}$ borgerlige kredse. Følelsen af indre sammenhold har af naturlige grunde været sværere at mobilisere hos samfundets dårligst stillede. Selv om billedet af "De sønderjydske Piger« også har hængt i mange arbejderhjem, har det ikke umiddelbart været muligt at finde eksempler på, at det nationale billede i disse hjem har bevirket en tilsvarende prægning.

$\mathrm{Vi}$ har fulgt et billedes forunderlige skæbne fra at blive skabt som en profitabel, letsælgelig vare til at blive et nationalt symbol, som har været levedygtig $\mathrm{i}$ henved $100 \mathrm{a}$. Billedet startede som en udpræget salgsvare - og det er endt på samme måde. Et af de få steder i handlen, hvor »De sønderjydske Piger« endnu kan ses, er $\mathrm{i}$ kiosken på Skamlingsbanken. Her sælges et postkort med Helga og Valborg Tofte anbragt sammen med Skamlingsbankestøtten (se fig. 20). De ledsagende vers er imidlertid hverken Bergsøes eller Drachmanns - men den lidt sentimentale Skamlingsbankevise. Postkortfirmaet har sikkert kalkuleret med, at ingen kunne huske den rette sammenhæng med to piger. Man har da noget frimodigt kombineret de to gamle og velanskrevne, nationale symboler og tilsat et solidt stænk af populærkultur med den sødladne sang.

Lad dette billede være den bittersøde afslutning på denne beretning, da det understreger, at vi i nutiden ikke kan bruge den nationale symbolik til ret meget andet end kommercielle formål. Det skyldes især, at de holdninger, symbolerne er udtryk for, ikke svarer til nutidens behov. Ingen ved nemlig rigtig, hvad man skal stille op med nationalitetsbegrebet $i$ en tid, hvor de 


\section{Sfamlingsbanten.}
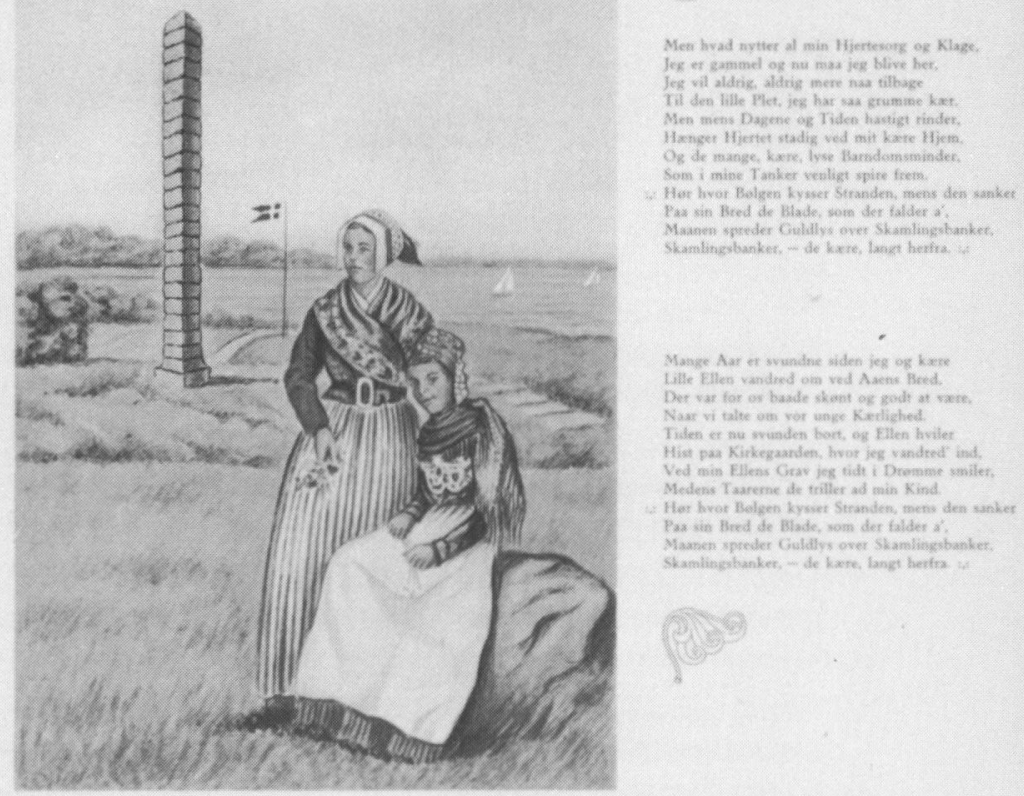

Fig. 20: Postkort med ritlen "Originalt motiv af senderjyske nationaldragter og den originale Skamlingsbankesangw. Et eksempel pd̊ en ikke blot pietetsles, men därlig, nutidig gengivelse af kendte symboler: Skamlingsbankestotten er fremstillet uden sine ar, pigerne er spejlvendte iforhold til originalen, Valborgs lommetorklade og hovedvandsag er udskiftet med en blomsterbuket, og den ellers tungsindige og alvorlige Helga sidder her og smiler huldsaligt. Museet på Sonderborg Slot.

borgerlige partier, der tidligere var meget nationale, i stigende grad er blevet internationalt orienterede, mens modstanden mod EF, NATO og suverænitetsafgivelse hovedsageligt samles i de socialistiske partier, som i deres udspring var internationalistiske. Det må øge forvirringen hos mange, at gamle nationale symboler som f.eks. Holger Danske bliver hentet fra glemslen og anvendt i valgkamp af venstrefløjen. Denne skæbne har »De sønderjydske Piger« dog hidtil undgået.

Nationale symboler prøver at være udtryk for, at der findes fælles værdier og holdninger i en nation. Ofte får symbolerne imidlertid karakter af at være postulater, og de bliver ikke folkeeje, dvs. alment accepterede. Forudsatningen for at et nationalt symbol også kan blive et folkeligt symbol - således som Bojesens billede blev det - er, at det rummer et budskab, som mange kan identificere sig med. "De sønderjydske Piger«s budskab er, at vi danskere trods magtesløshed og svaghed - skal være udholdende og trofaste over for vor kulturarv.

De fleste andre nationale symboler søger at fremme den kollektive identifi- 
kation gennem en helteskikkelse; dette er f.eks. tilfældet med Germania, Moder Danmark og John Bull. Set i denne sammenhæng er »De sønderjydske Piger« enestående ved ikke at appellere til magt.

\section{NOTER OG HENVISNINǴER}

1. De sønderjyske piger var bagsiden af almanakken 1896-1914 og 1960-1980. Se også Troels Fink: Almanakkens bagside. (I: Sprogforeningens Almanak for 1980, s. 33-44).

2. Der kan bl.a. nævnes Chr.Knudsen: En sønderjysk Slægt. De sønderjyske Piger og deres Fader (I: Sprogforeningens Almanak for 1924 s. 56-66) og samme: Den sidste af »de sønderjyske Piger« (I: Sprogforeningens Almanak for 1931, s. 31-32).

3. Bertha Hahn: Minder fra Sønderborg og Als 1850-70. Kbh. 1913. Her efter 2. udgave, Sønderborg 1978, s. 76.

4. Povl Drachmann i forordet til genforeningsudgaven af Derovre fra Gransen, Kbh. 1919 s. 9.

5. Holger Drachmann: Derovre fra Gransen. 1877. Her efter 2. udg. 1919, s. 138-39.

6. Derovre fra Gransen, 2. udg. s. 127 28. De to sidste strofer er her udeladt. Til bogen havde Drachmann skrevet en række andre nationale digte, men kun digtet om Bøffelkobbel-graven vandt udbredelse.

7. H.P. Rhode: Ernst Bojesen. Storforlaggeren i Humer, Kunst og Oplysning. Kbh. 1958, s. 38.

8. Ernst Bojesen i Politiken, 27. maj 1919.

9. Smstds.

10. Chr. Knudsen, 1924, s. 58.

11. Om højskolen i Aagaard se Dorrit Andersen: J.A. Viinstedt og højskolen i Aagaard (I: Sønderjyske Arboger, 1983, s. 77-104).

12. Valborgs udtalelse om dragter er gengivet i en kronik af P.Siim i ugebladet Fadrelandet, 1911, s. $44-45$.

13. Hele digtet gengives i Sonderjysk Månedsskrift, 1948, s. 78.

14. Aage Holm Rasmussen: Lærer i et Grænseland (I: Senderjysk Månedsskrift, 1970, s. 322).

15. Se f.eks. Ema Lorenzen: Hvem sagde Nationaldragt? Århus 1987.

16. A.Holst Jørgensen i en kronik i Flensborg Avis 14. maj 1949 og P.Siim i Fædrelandet, 22. jan. 1911.

17. Nordisk Boghandlertidende, 8. aug. 1879.

18. Vedr. Julius Strandbergs produktion se Iørn Piø: Julius Strandbergs Skillingsviseproduktion 1861-1903 (I: Folk og Kultur, 1974, s. 17-49).

19. Politiken, 27. maj 1919.

20. Ugebladet Fadrelandet, 22. jan. 1911.

21. P. Fristrup: Scenens Navne, 1913, s. 158.

22. Smstds. s. 159.

23. E. Bodenhoff: Fra Dannevirke til Als, 1905, s. 59.

24. Marie Skau-Petersen: De sønderjydske Piger i København 1884 (I: Sonderj.sk Månedsskrift, årg. 9, 1932-33, s. 106).

25. Vedr. symbolet Mor Danmark, se Inge Adriansen: Mor Danmark, valkyrie, skjoldmø og fædrelandssymbol (I: Folk og Kultur, 1987, s. 105-163).

26. Jvf. oplysninger fra den nuværende formand for Sprogforeningen, Jørgen Mågård.

27. Anna Kjems: Kniplinger og Knapkager. 1983, s. $24 \mathrm{f}$.

28. Nicolai Svendsen og Svend Thorsen: Tiende Februar. Livsbilleder fra Sonderjylland i Genforeningsåret 1920,1939, s. 79.

29. Chr. Demuth: Håb og Tro (I: DSK-Arbogen 1956, s. 1-4).

30. Digtet er trykt i Sprogforeningens Almanak 1924, s. 66. 